\title{
Model for the Sustainable Material Selection by Applying Integrated Dempster-Shafer Evidence Theory and Additive Ratio Assessment (ARAS) Method
}

\author{
Seyed Morteza Hatefi ${ }^{1}$ (D) Hamideh Asadi ${ }^{1}$, Gholamreza Shams ${ }^{1}$, Jolanta Tamošaitiene ${ }^{2, *}$ (D) \\ and Zenonas Turskis ${ }^{2}$ (D)
}

1 Department of Civil Engineering, Faculty of Engineering, Shahrekord University, Rahbar Boulevard, P.O. Box 115, Shahrekord 881863414, Iran; smhatefi@alumni.ut.ac.ir (S.M.H.); asadihamideh5@gmail.com (H.A.); g.shams@sku.ac.ir (G.S.)

2 Institute of Sustainable Construction, Faculty of Civil Engineering, Vilnius Gediminas Technical University, Saulètekio al. 11, LT-10223 Vilnius, Lithuania; zenonas.turskis@vilniustech.lt

* Correspondence: jolanta.tamosaitiene@vilniustech.lt

check for

updates

Citation: Hatefi, S.M.; Asadi, H.; Shams, G.; Tamošaitienè, J.; Turskis, Z. Model for the Sustainable Material Selection by Applying Integrated Dempster-Shafer Evidence Theory and Additive Ratio Assessment (ARAS) Method. Sustainability 2021, 13, 10438. https://doi.org/10.3390/ su131810438

Academic Editor: Antonio Caggiano

Received: 25 June 2021

Accepted: 30 August 2021

Published: 18 September 2021

Publisher's Note: MDPI stays neutral with regard to jurisdictional claims in published maps and institutional affiliations.

Copyright: (c) 2021 by the authors. Licensee MDPI, Basel, Switzerland. This article is an open access article distributed under the terms and conditions of the Creative Commons Attribution (CC BY) license (https:/ / creativecommons.org/licenses/by/ $4.0 /)$.

\begin{abstract}
The construction industry is a vital part of the modern economic system. Construction work often has significant negative impacts on the environment and sustainable economic development, such as degradation of the environment, depletion of resources, and waste generation. Therefore, environmental concerns must be taken into account when evaluating and making decisions in the construction industry. In this regard, sustainable construction is considered as the best way to avoid resource depletion and address environmental concerns. Selection of sustainable building materials is an important strategy in sustainable construction that plays an important role in the design and construction phase of buildings. The assessment of experts is one of the most important steps in the material selection process, and their subjective judgment can lead to unpredictable uncertainty. The existing methods cannot effectively demonstrate and address uncertainty. This paper proposes an integrated Dempster-Shafer (DS) theory of evidence and the ARAS method for selecting sustainable materials under uncertainty. The Dempster-Shafer Evidence Theory is a relatively new and appropriate tool for substantiating decisions when information is nonspecific, ambiguous, or conflicting. The Additive Ratio Assessment (ARAS) method has many advantages to deal with MCDM problems with non-commensurable and even conflicting criteria and to obtain the priority of alternatives based on the utility function. The proposed method converts experts' opinions into the basic probability assignments for real alternatives, which are suitable for DS evidence theory. It uses the ARAS method to obtain final estimation results. Finally, a real case study identifying the priority of using five possible alternative building materials demonstrates the usefulness of the proposed approach in addressing the challenges of sustainable construction. Four main criteria including economic, social, environmental, and technical criteria and 25 sub-criteria were considered for the selection of sustainable materials. The specific case study using the proposed method reveals that the weight of economic, socio-cultural, environmental, and technical criteria are equal to 0.327 , $0.209,0.241$, and 0.221 , respectively. Based on these results, economic and environmental criteria are determined as the most important criteria. The results of applying the proposed method reveal that aluminum siding with a final score of 0.538 , clay brick with a score of 0.494 , and stone façade with a final score of 0.482 are determined as the best alternatives in terms of sustainability.
\end{abstract}

Keywords: material selection; sustainability; Dempster-shafer evidence theory; MCDM; ARAS; BWM

\section{Introduction}

All operations related to the construction, operation, or demolition of a building affect the environment in various ways and can be considered as environmental factors [1,2]. Because of depleting resources and environmental concerns, researchers and practitioners 
have begun to explore sustainable construction strategies. Human health and the environment will be at a disadvantage and greenhouse gases will destroy the ozone layer if the devastating effects of this part of the economic system are not considered. It is argued that the most critical factors in natural disasters are environmental issues and hazards [3,4]. Figure 1 presents the model for sustainable material selection.

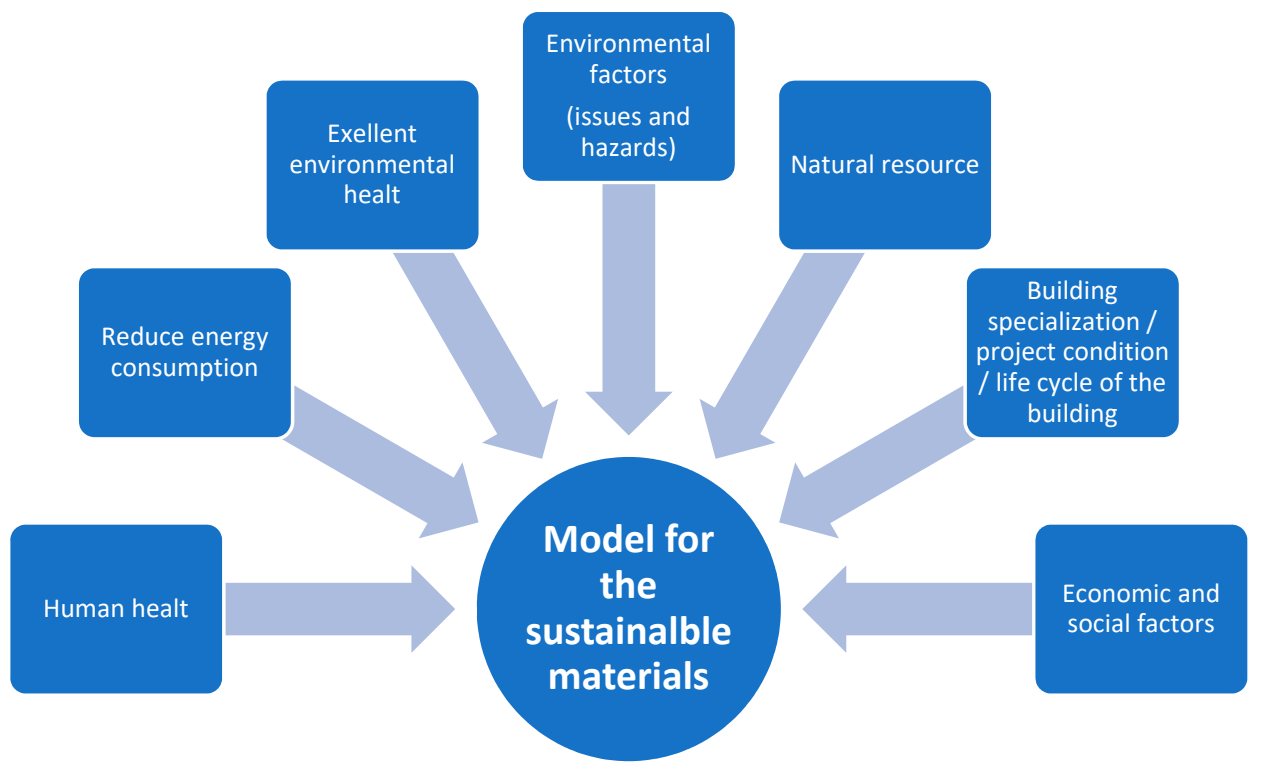

Figure 1. The model for sustainable material selection.

Advances in science and technology have changed the environment to meet the needs of human well-being [5]. The extraction of raw materials needed for construction, such as wood, sand, clay, and others, causes irreversible effects on the natural environment. A well-designed building made of sustainable materials is less harmful to the environment and improves the life cycle of the building. Such a building will also significantly reduce life cycle costs [6-8].

Three principles of development, considering building as a part of the environment including economic and social components $[9,10]$, are the basis for defining sustainable construction of the human-built environment. Sustainable building addresses not only environmental sustainability but also economic and social sustainability. Moreover, the sustainable concept is closely related to both international and local perspectives [11]. The sustainable building benefits the economy by reducing operating costs, enhancing marketability, improving employee productivity and productivity, creating benefits for office buildings, minimizing adverse impacts and interiors, and enhancing the economic performance of the building life cycle $[10,12,13]$. Proper construction and environmental protection of materials used in buildings are essential. The choice of sustainable and suitable building materials will reduce energy consumption, provide better environmental health, reduce the use of natural resources [14-16], and reduce waste generation [17]. Using suitable materials is one way to achieve sustainable architecture and thus manage environmental hazards more efficacious $[18,19]$. Unfortunately, potential risk factors and a lack of accurate knowledge by stakeholders in a dynamic business environment expose construction projects [20].

Esin [21] classified the material selection factors into three groups: functional, financial, and maintenance. Functional requirements are essential for a proper comparison of the materials. Variants include functional and technical requirements that define measurable criteria such as hardness and stiffness.

Akadiri et al. [22] provided sustainable evaluation criteria for the selection of building materials. First, based on previous research results, the authors selected the criteria for 
choosing materials. They determined the data to compare the choices according to the answers provided by experts.

Various methods are helpful for solving sustainable material selection problems. For instance, Mousavi-Nasab and Sotoudeh-Anvari [23] proposed a new multi-criteria decisionmaking (MCDM) way to select materials. The presented method generates more logical results than those obtained by three of the most popular techniques in the material selection area. Roy et al. [4] proposed an MCDM evaluation framework by extending the COmbinative Distance ASsessment (CODAS) method [24] with interval-valued intuitionistic fuzzy numbers. Mathiyazhagan et al. [8] applied a three-stage approach to select materials under a fuzzy environment. The authors selected 23 sub-criteria, employed the Best-Worst methodology (BWM) [25] to determine criteria and sub-criteria weights, and used fuzzy TOPSIS to evaluate materials.

Govindan et al. [26] proposed an integrated DEMATEL-ANP-TOPSIS [27-29] approach to select materials. The authors utilized DEMATEL to determine the interrelationship among evaluation criteria, employed ANP to determine the weights, and applied TOPSIS to evaluate the performance of available alternatives. Mahmoudkelaye et al. [30] presented other applications of the ANP methods for sustainable material selection.

Zavadskas et al. [31] presented a theoretical evaluation model based on the SWARA (Step-wise Weight Assessment Ratio Analysis) [32] approach and MULTIMOORA (multiobjective optimization by ratio analysis plus full multiplicative form) [33] method for residential house construction materials and elements selection. Chen et al. [34] proposed a multiple criteria group decision-making approach based on a quality function deployment (QFD) and ELECTRE III method for sustainable material selection. Reddy et al. [35] introduced a sustainable material performance index based on the social, environmental, economic, and technological criteria for selecting sustainable material in the construction industry.

Most authors use methods for assessing the sustainability of materials under certain conditions. Additionally, some of the authors used concepts and practices in their reports to cover data uncertainties related to the values of the evaluation criteria. This paper presents the Dempster-Shafer Evidence Theory-based selection model to substantiate uncertain information in expert conclusions on material evaluation criteria. Evidence theory is a new powerful tool for decision-making, handling uncertain information, and managing conflicting information. The purpose of this work is to provide a model for justifying effective choices based on Dempster-Shafer Evidence Theory and the ARAS method for evaluating materials based on sustainability characteristics. In addition, the authors use the ARAS method to assess and select sustainable options.

Zavadskas and Turskis developed the ARAS method in 2010 [36]. Table 1 presents a review of the ARAS method modifications and applications.

Table 1. The review of the ARAS method modifications and applications.

\begin{tabular}{ccccc}
\hline Year & ARAS & Extended ARAS Method & Applications for the Assessment & Literature Reference \\
\hline \multirow{2}{*}{2010} & ARAS & ARAS-F & & {$[36]$} \\
& & ARAS-G & {$[37]$} \\
& ARAS & & Foundation Instalment & {$[38]$} \\
\multirow{2}{*}{2011} & ARAS & ARAS-F & Pile-Columns & {$[39]$} \\
\hline \multirow{2}{*}{2012} & ARAS & Architect Selection & {$[40]$} \\
& ARAS & Experimental Study on Technological & {$[41]$} \\
\hline \multirow{2}{*}{2013} & ARAS & Indicators of Pile-Columns & {$[42]$} \\
& ARAS & Projects Managers & {$[43]$} \\
& \multirow{3}{*}{ ARAS-G } & Lithuanian Economic Sectors & {$[44]$} \\
\hline
\end{tabular}


Table 1. Cont.

\begin{tabular}{|c|c|c|c|c|}
\hline Year & ARAS & Extended ARAS Method & Applications for the Assessment & Literature Reference \\
\hline \multirow{4}{*}{2014} & & ARAS-F & Selection of the Chief Accountant & [47] \\
\hline & & Fuzzy GARAS & Waste Dump Site Selection & [48] \\
\hline & & Fuzzy ARAS & Model for Extending Brand & [49] \\
\hline & & ARAS-F & Financial Performance Evaluation & [50] \\
\hline \multirow{3}{*}{2015} & ARAS & ARAS-F & $\begin{array}{c}\text { Deep-Water Port in the Eastern Baltic Sea } \\
\text { Sustainable Building } \\
\text { Assessment/Certification }\end{array}$ & $\begin{array}{l}{[51]} \\
{[19]}\end{array}$ \\
\hline & & $\begin{array}{l}\text { ARAS with interval-valued } \\
\text { triangular fuzzy }\end{array}$ & & [52] \\
\hline & & ARAS-F & & {$[53]$} \\
\hline \multirow{7}{*}{2016} & ARAS & & Ranking of Companies & [54] \\
\hline & ARAS & & Biomass Selection & [55] \\
\hline & ARAS & & Personnel Selection & [10] \\
\hline & ARAS & & $\begin{array}{l}\text { Model to Assess a Stairs Shape for } \\
\text { Dwelling }\end{array}$ & [56] \\
\hline & & PMADM & & [57] \\
\hline & & Fuzzy ARAS & & [58] \\
\hline & ARAS & & $\begin{array}{l}\text { Evaluation of Research and Technology } \\
\text { Organizations Based on BSC Approach }\end{array}$ & [59] \\
\hline \multirow{5}{*}{2017} & ARAS & & Ranking of Energy Generation Scenarios & [60] \\
\hline & ARAS & & $\begin{array}{l}\text { Complicated Supply Chain Management } \\
\text { Problems }\end{array}$ & [61] \\
\hline & & ARAS-F & Personnel Assessment Problems & [62] \\
\hline & ARAS & & Negotiations & [63] \\
\hline & ARAS & & $\begin{array}{l}\text { Cultural Heritage Structures for } \\
\text { Renovation Projects }\end{array}$ & {$[64]$} \\
\hline \multirow{9}{*}{2018} & & ARAS-G & Personnel Selection & {$[65]$} \\
\hline & ARAS & & Evaluate Mobile Banking Services & [66] \\
\hline & ARAS & & $\begin{array}{c}\text { Selection of Optimum Process Parameters } \\
\text { in Turning Process }\end{array}$ & {$[67]$} \\
\hline & ARAS & & $\begin{array}{l}\text { Machinery/Service System Scheduled } \\
\text { Replacement Time Determination }\end{array}$ & {$[68]$} \\
\hline & ARAS & & Identification of Erosion-Prone Areas & [69] \\
\hline & & ARAS-F & $\begin{array}{c}\text { Evaluation of Organizational Strategy } \\
\text { Development }\end{array}$ & [70] \\
\hline & ARAS & & Selection of a Brake Disc Material & [71] \\
\hline & & rough ARAS & $\begin{array}{l}\text { Measuring Performance in Transportation } \\
\text { Companies }\end{array}$ & [72] \\
\hline & ARAS & & Determining the Utility in Management & [73] \\
\hline
\end{tabular}


Table 1. Cont

\begin{tabular}{|c|c|c|c|c|}
\hline Year & ARAS & Extended ARAS Method & Applications for the Assessment & Literature Reference \\
\hline \multirow{18}{*}{2019} & & NARAS & $\begin{array}{l}\text { Selection of Material for Optimal Design } \\
\text { of Engineering Components }\end{array}$ & [74] \\
\hline & ARAS & & Information System Fault-Tolerance & [75] \\
\hline & & Fuzzy ARAS & $\begin{array}{l}\text { Determination of Individuals' Life } \\
\text { Satisfaction Levels Living }\end{array}$ & [76] \\
\hline & & AHP-ARAS & $\begin{array}{l}\text { EDM Process Parameters on Machining } \\
\text { AA7050-10\%B4C Composite }\end{array}$ & [77] \\
\hline & & ARAS-F & Supplier Selection & [78] \\
\hline & & IVIF-ARAS & Smartphone Selection Problem & [79] \\
\hline & & ARAS-G & $\begin{array}{c}\text { Construction Delay Change Response } \\
\text { Problem }\end{array}$ & [80] \\
\hline & & ARAS-F & $\begin{array}{l}\text { Assessment of Structural Solutions of the } \\
\text { Symmetric Frame Alternatives }\end{array}$ & [81] \\
\hline & ARAS & & Catering Supplier Selection & [82] \\
\hline & ARAS & & $\begin{array}{l}\text { Sustainable Supplier Selection in a } \\
\text { Construction Company }\end{array}$ & [83] \\
\hline & & ARAS-IT2HFSs & Underground Site Selection: & [84] \\
\hline & & fuzzy ARAS & Personnel Selection Problem & [85] \\
\hline & & FCM-ARAS & Financial Performance & [86] \\
\hline & ARAS & & $\begin{array}{l}\text { Selecting a Suitable Maintenance Strategy } \\
\text { for Public Buildings using Sustainability } \\
\text { Criteria }\end{array}$ & [87] \\
\hline & & Entropy-ARAS & $\begin{array}{l}\text { Assessing Corporate Sustainability } \\
\text { Performances of Privately-owned Banks }\end{array}$ & [88] \\
\hline & ARAS & & Evaluating Autonomous Vehicles & [89] \\
\hline & & BWM-ARAS & Prospectivity Mapping & [90] \\
\hline & & fuzzy ARAS & Supplier Selection Problem & [91] \\
\hline \multirow{8}{*}{2020} & ARAS & & Analysis of Companies' Digital Maturity & [92] \\
\hline & ARAS & & Location Selection for Logistics Center & [93] \\
\hline & ARAS & & $\begin{array}{c}\text { Location Preferences of new Pedestrian } \\
\text { Bridges }\end{array}$ & [94] \\
\hline & & hybrid SWARA-ARAS & $\begin{array}{l}\text { Sustainability Indicators for Renewable } \\
\text { Energy Systems }\end{array}$ & [95] \\
\hline & & HFLTS- ARAS & Selection of Eco-friendly Cities & [96] \\
\hline & & F-ARAS & $\begin{array}{c}\text { Prioritizing the Outsourcing Performance } \\
\text { Outcomes }\end{array}$ & [97] \\
\hline & & IF-ARAS & Personnel Selection & [98] \\
\hline & & $\begin{array}{l}\text { PIPRECIA-Interval-Valued } \\
\text { Triangular Fuzzy ARAS }\end{array}$ & E-Learning Course Selection & [99] \\
\hline
\end{tabular}

The rest of this article is organized as follows. Section 2 presents the aim and objectives of the paper. Section 3 describes the Dempster-Shafer Evidence Theory and the ARAS method. Next, Section 4 presents the proposed integration of the Dempster-Shafer Evidence Theory and the ARAS method. Section 5 shows the use of the presented methodology to evaluate five sustainable materials for the building facade. The last section gives concluding remarks. 


\section{Aim and Objectives}

The choice of sustainable materials can be considered as an MCDM problem in which a set of alternatives should be evaluated based on several sustainability criteria. These criteria, alternatives, and tier-respected information form the decision matrix in the MCDM problem. In this paper, the ARAS method is used to evaluate and prioritize alternatives. In reality, it is very difficult to determine the value of the criteria accurately, and in many cases the information that can be collected is uncertain. Therefore, to model the MCDM problem for sustainable material selection, a case study has been conducted in this paper that focuses on information that has uncertainty and can be expressed in terms of the basic probability assignments in the evidence theory. Accordingly, each of the matrix elements of the decision matrix is expressed as a basic probability assignment. The rule of composition is used to prepare the final decision matrix, and the elements of the decision matrices of all experts are fused to obtain the final decision matrix. This matrix is later used in the ARAS method. In addition, to determine the importance of the criteria, a weighting method based on evidence theory is utilized in this paper, and based on it, the decision matrix used in the ARAS method is weighted.

This paper aims to introduce an evidential model based on DS evidence theory and the ARAS method to solve the problem of sustainable material selection under uncertainty. The primary objectives of this paper are summarized below:

- Objective 1: Introducing a practical way to extract the basic probability assignments from the evaluation of information of experts by expressing linguistic terms and confidence levels. This is an effective way to deal with uncertain information in MCDM problems in which decision-makers can consider the evaluation itself without formality and can also employ imperfect or insufficient knowledge of data.

- Objective 2: Obtaining the final decision matrix in terms of the basic probability assignments. The final decision matrix is obtained based on fusion results and is employed later in the ARAS method.

- $\quad$ Objective 3: Applying a weighting method based on the Deng entropy for determining the weights of sustainability criteria. These weights will be employed to obtain the weighted decision matrix.

- $\quad$ Objective 4: Applying the ARAS method on the decision matrix to obtain the ranking results and prioritize alternatives (sustainable materials).

\section{Preliminaries}

\subsection{Dempster-Shafer Theory of Evidence}

Dempster-Shafer's theory of evidence is a valuable tool to cope with the substantial uncertainty in the experts' opinions. Dempster in 1967 introduced this theory, and then Shafer in $1976[100,101]$ expanded it. This theory is a powerful way to combine evidence extracted from different sources. The belief functions used in Dempster-Shafer's theory of evidence, compared to probability theory, provide more information to support decisionmaking by unknown and uncertain evidence and a mechanism for deriving solutions to ambiguous and different evidence without prior information and possibilities. This theory has successful applications in many fields, including knowledge reduction [102], error detection [103], multi-class classification [104], supplier selection [105], and others.

\subsubsection{Mass Function}

In the Dempster-Shafer Evidence Theory, also referred to as the DS Theory of Evidence, a set of elementary hypotheses such as $H_{1}, H_{2}, \ldots, H_{n}$ define the frame of discernment as follows [106]:

$$
\theta=\left\{H_{1}, H_{2}, \ldots, H_{n}\right\}
$$

where $\theta$ denotes a set of mutually exclusive and collectively exhaustive events. A nomenclature table is added in Appendix A to define the variables and notations used in the paper. 
The power set of $\theta$ is denoted by $2^{\theta}$. The mass function, which is called a basic probability assignment (BPA), is a mapping from the power set to the interval [0, 1] as follows [107]:

$$
m: 2^{\theta} \rightarrow[0,1] .
$$

The mass function satisfies the following properties:

$$
\begin{gathered}
m(\theta)=0 \\
\sum_{A \in 2^{\theta}} m(A)=1
\end{gathered}
$$

where $A$ is a member of the power set. If $m(A)>0$, then $A$ is called a focal element of the mass function.

\subsubsection{Deng Entropy and the Weight of BPAs}

Deng [107] introduced the new entropy measure called Deng entropy to measure the uncertainty degree of BPAs. Deng entropy is an extended form of Shannon entropy and is denoted by $E(B P A)$. Deng entropy is obtained as follows:

$$
E(B P A)=-\sum_{i} m\left(F_{i}\right) \log \frac{m\left(F_{i}\right)}{2^{\left|F_{i}\right|}-1} .
$$

where $E(B P A)$ denotes Deng entropy, $F_{i}$ is a proposition in mass function $m, m\left(F_{i}\right)$ denotes the mass function of $F_{i}$, and $\left|F_{i}\right|$ denotes the number of elements of $F_{i}$. The following equation calculates the maximum value of Deng entropy $\left(E_{\max }\right)$ :

$$
E_{\max }=-\sum_{i} m\left(F_{i}\right) \log \frac{m\left(F_{i}\right)}{2^{\left|F_{i}\right|}-1}
$$

If and only if

$$
m\left(F_{i}\right)=\frac{2^{\left|F_{i}\right|}-1}{\sum_{i} 2^{\left|F_{i}\right|}-1}
$$

Considering the quality of information and the existing uncertainty in experts' judgments is very important before combining evidence. Fei et al. [106] reflected this matter by calculating the weight of the BPAs and modifying BPAs based on their weights before combining them. According to Fei et al. [106], the weight of a given BPA can be determined as follows:

$$
w(B P A)=1-\frac{E(B P A)}{E_{\max }}
$$

where $w(B P A)$ denotes the weight of a given BPA, $E(B P A)$ is the Deng entropy for a given $\mathrm{BPA}$, and $E_{\max }$ is the maximum value of Deng entropy

\subsubsection{Discounted BPA}

The basic probability assignment can be modified by a discounting coefficient denoted by $\alpha$. When the evidence is believed by probability $\alpha$, the discounted BPA is obtained by the following equations:

$$
\begin{gathered}
m^{\alpha}(A)=\alpha \times m(A) \quad A \in \theta \\
m^{\alpha}(\theta)=(1-\alpha) \times m(\theta)
\end{gathered}
$$

where $A$ is the focal element of the mass function $m$ [106]. The weight of BPA can be considered as the discounting coefficient to reduce the uncertainty degree in the evidence. 


\subsubsection{Dempster's Rule of Combination}

To combine two BPAs $m_{1}$ and $m_{2}$, Dempster's rule of combination is used. The combined evidence is denoted by $m=m_{1} \oplus m_{2}$ and calculated as follows:

$$
\begin{gathered}
m(A)=\frac{1}{1-k} \sum_{B \cap C=A} m_{1}(B) m_{2}(C), \\
k=\sum_{B \cap C=\theta} m_{1}(B) m_{2}(C)
\end{gathered}
$$

where $k$ states the conflict between two BPAs $m_{1}$ and $m_{2}$, and $m(A)$ shows the combined BPA.

If there are more than two BPAs for combinations, the extended Dempster's rule of combination is applied as follows:

$$
m=m_{1} \oplus m_{2} \oplus \cdots \oplus m_{L}=\left(\left(\left(\left(m_{1} \oplus m_{2}\right) \oplus m_{3}\right) \oplus \cdots\right) \oplus m_{L}\right)
$$

\subsubsection{Pignistic Probability Transformation}

A probability that a rational person will assign to an option when required to decide is a pignistic probability. Let $m$ be a BPA on the frame of discernment $\theta$. The following equation obtains the pignistic probability transformation for a given singleton $x \in \theta$. The goal of pignistic probability transformation is to convert a BPA to a probability distribution for decision making.

$$
\operatorname{BetP}\{x\}=\sum_{x \in A \subset \theta} \frac{1}{|A|} \frac{m(A)}{1-m(\theta)}, m(\theta) \neq 1 .
$$

where $|A|$ denotes the cardinality of proposition $A$, and $\operatorname{BetP}\{x\}$ shows the pignistic probability transformation for $x \in \theta$.

\subsection{Additive Ratio Assessment (ARAS) Method}

ARAS is a relatively new technique in multi-attribute decision making that has attracted researchers in recent years. Zavadskas and Turskis [36] introduced this technique in 2010. In this method, alternatives are ranked based on the optimality criterion. The steps of implementing the ARAS method are as follows [36]:

Step 1: In the first step, the decision-making matrix is formed. The dimension of this matrix is $m \times n$, where $m$ denotes the number of alternatives (rows) and $n$ shows the number of criteria (columns).

$$
X=\left[\begin{array}{ccccc}
x_{01} & \cdots & x_{0 j} & \cdots & x_{0 n} \\
\vdots & \ddots & \vdots & \ddots & \vdots \\
x_{i 1} & \cdots & x_{i j} & \cdots & x_{i n} \\
\vdots & \ddots & \vdots & \ddots & \vdots \\
x_{m 1} & \cdots & x_{m j} & \cdots & x_{m n}
\end{array}\right], \quad i=0,1, \ldots, m, j=1,2, \ldots, n
$$

where $X$ denotes the decision-making matrix, $x_{i j}$ denotes the rating of alternative $i$ for criterion $j$, and $x_{0 j}$ presents the optimal value of $j$ th criterion. If $x_{0 j}$ is unknown, then it is obtained by the following equations for the benefit and cost type criteria:

$$
\begin{aligned}
x_{0 j} & =\operatorname{Max}_{i} x_{i j} \text { if } \operatorname{Max}_{i} x_{i j}, \text { is preferable } \\
x_{0 j} & =\operatorname{Min}_{i} x_{i j} \text { if } \operatorname{Min}_{i} x_{i j}, \text { is preferable }
\end{aligned}
$$

where $x_{0 j}$ denotes the optimal value of $j$ th criterion. Typically, optimal values are values that cannot be better in any way. Equation (13) is valid when stakeholders consider all possible alternatives, and there is no suitable alternative. This condition ensures that even if an option to include in or to remove it from the list of options in the research 
case, the options' performance remains the same, and the performance level of considered alternatives is the same. This method ensures that the technique is resistant to changes in ratings (rank reversals). For example, if decision-makers are looking for options with a maximum return of 1 , the expected optimal value is 1.2. For cost type criteria, this value is 0.8 if the least value is 1 . When linguistic terms express the level of performance, then the maximum available linguistic value describes the optimal variant $\left(x_{0 j}=5\right)$. Additionally, the decision-maker is real (equal to 1 in the case study).

Step 2: In the second step, the normalized decision-making matrix $(\bar{X})$ whose elements are denoted by $\bar{x}_{i j}$ is obtained. The dimension of this matrix is $m \times n$.

$$
\bar{X}=\left[\begin{array}{ccccc}
\bar{x}_{01} & \cdots & \bar{x}_{0 j} & \cdots & \bar{x}_{0 n} \\
\vdots & \ddots & \vdots & \ddots & \vdots \\
\bar{x}_{i 1} & \cdots & \bar{x}_{i j} & \cdots & \bar{x}_{i n} \\
\vdots & \ddots & \vdots & \ddots & \vdots \\
\bar{x}_{m 1} & \cdots & \bar{x}_{m j} & \cdots & \bar{x}_{m n}
\end{array}\right], \quad i=0,1, \ldots, m, j=1,2, \ldots, n
$$

where $\bar{X}$ denotes the normalized decision-making matrix. The following formula normalizes the benefit type criteria:

$$
\bar{x}_{i j}=\frac{x_{i j}}{\sum_{i=0}^{m} x_{i j}}
$$

Furthermore, the following formulas normalize the cost type criteria:

$$
x_{i j}=\frac{1}{x_{i j}^{*}}, \quad \bar{x}_{i j}=\frac{x_{i j}}{\sum_{i=0}^{m} x_{i j}}
$$

Step 3: In this step, the normalized-weighted decision-making matrix $(\hat{X})$ is provided. Let $w_{j}$ be the weight of $j$ th criterion and the weights of criteria satisfy the equation $\sum_{j=1}^{n} w_{j}=1$. Deng entropy can be employed to obtain the weight of criteria. According to the [42], the weight of the $j$ criterion can be formulated as follows:

$$
w_{j}=\frac{D_{j}}{\sum_{j=1}^{n} D_{j}},
$$

where $w_{j}$ is the weight of the $j$ criterion and $D_{j}$ denotes the consistency of alternatives for $j$ criterion and calculated as:

$$
D_{j}=1-E_{j},
$$

where $E_{j}$ denotes the entropy of $j$ criterion, which is calculated based on the Deng entropy according to the following equation.

$$
E_{j}=-\sum_{i} m_{j}\left(F_{i}\right) \log \frac{m_{j}\left(F_{i}\right)}{2^{\left|F_{i}\right|}-1}
$$

The elements of the normalized-weighted decision-making matrix $(\hat{X})$ are denoted by $\hat{x}_{i j}$ and calculated as follows:

$$
\hat{X}=\left[\begin{array}{ccccc}
\hat{x}_{01} & \cdots & \hat{x}_{0 j} & \cdots & \hat{x}_{0 n} \\
\vdots & \ddots & \vdots & \ddots & \vdots \\
\hat{x}_{i 1} & \cdots & \hat{x}_{i j} & \cdots & \hat{x}_{i n} \\
\vdots & \ddots & \vdots & \ddots & \vdots \\
\hat{x}_{m 1} & \cdots & \hat{x}_{m j} & \cdots & \hat{x}_{m n}
\end{array}\right], \quad i=0,1, \ldots, m, j=1,2, \ldots, n
$$




$$
\hat{x}_{i j}=w_{j} \bar{x}_{i j}, \quad i=0,1, \ldots, m
$$

Step 4: In this step, the optimality function and the utility degree of alternatives are calculated. The optimality function for alternative $i$ is formulated as:

$$
S_{i}=\sum_{j=1}^{n} \hat{x}_{i j}, \quad i=0,1, \ldots, m
$$

where $S_{i}$ denotes the optimality function of alternative $i$. The most significant value of $S_{i}$ is the best, and the least one is the worst. The higher the value of $S_{i}$ for $i$ th alternative, the more useful alternative. The alternative utility $K_{i}$ is determined by comparing the utility degree of alternative $i$ with the ideally best one $S_{0}$. Alternatives can be prioritized based on their utility degree. The alternative utility can be written as follows:

$$
K_{i}=\frac{S_{i}}{S_{0}}, \quad i=0,1, \ldots, m
$$

where $K_{i}$ denotes the alternative utility, which can take a value in the interval $[0,1]$. The larger the value of $K_{i}$, the preferable alternative.

\section{The Proposed DS Evidence Theory and the ARAS Method}

This section presents the proposed DS evidence theory and the ARAS method for the sustainable material selection problem. The assessment of experts is one of the most important steps in the material selection process. The subjective judgment of experts may lead to unpredictable uncertainty. The existing approaches such as fuzzy set theory and the Bayesian method cannot effectively handle uncertainty. Fuzzy set theory is an effective tool to handle epistemic uncertainty, which comes from the lack of information. However, it cannot effectively reflect the conflicting information extracted from multiple sources. The DS method is an efficient tool to support decisions when information is nonspecific, ambiguous, or conflicting. The DS method is an extended form of the Bayesian method that has all its advantages. For example, in the DS method, as in the Bayesian method, existing prior information can be incorporated into the inference of uncertain indices and inferential results. However, the use of prior information in the DS method is not mandatory. This is one of the advantages of the DS method. Second, the DS method, unlike other possible methods such as the Bayesian method, does not require a previous probability calculation. Third, it has a flexible and understandable mass function. Fourth, providing the mass function is easy and convenient. Fifth, the computational complexity of this method is much less than the Bayesian method. All aforementioned discussions show the reasons for choosing the DS theory of evidence for handling uncertainty. The ARAS method has many advantages to deal with MCDM problems with non-commensurable and even conflicting criteria. In the ARAS method, the priorities of alternatives are determined based on the utility function value. Furthermore, the ratio with an optimal alternative is used when seeking to rank alternatives and find ways of improving alternatives. This paper proposed an integrated DS evidence theory and the ARAS method to solve the sustainable material selection problem, which uses the features of both evidence theory and the ARAS method.

How to select the best material can be stated as a multi-criteria decision-making problem. According to the multi-criteria decision-making problem, there are $m$ alternatives $\left(A_{1}, A_{2}, \ldots, A_{m}\right)$, which must be evaluated by $n$ criteria $\left(C_{1}, C_{2}, \ldots, C_{n}\right)$. Furthermore, let $x_{i j}$ denotes the rating of alternative $i$ for criterion $j$. The proposed method for sustainable material selection is depicted in Figure 2. As it can be seen in this Figure, the proposed method has four main parts including determine linguistic terms, construct BPAs, obtain a decision matrix, and prioritize alternatives. The proposed method includes several steps, as follows: 


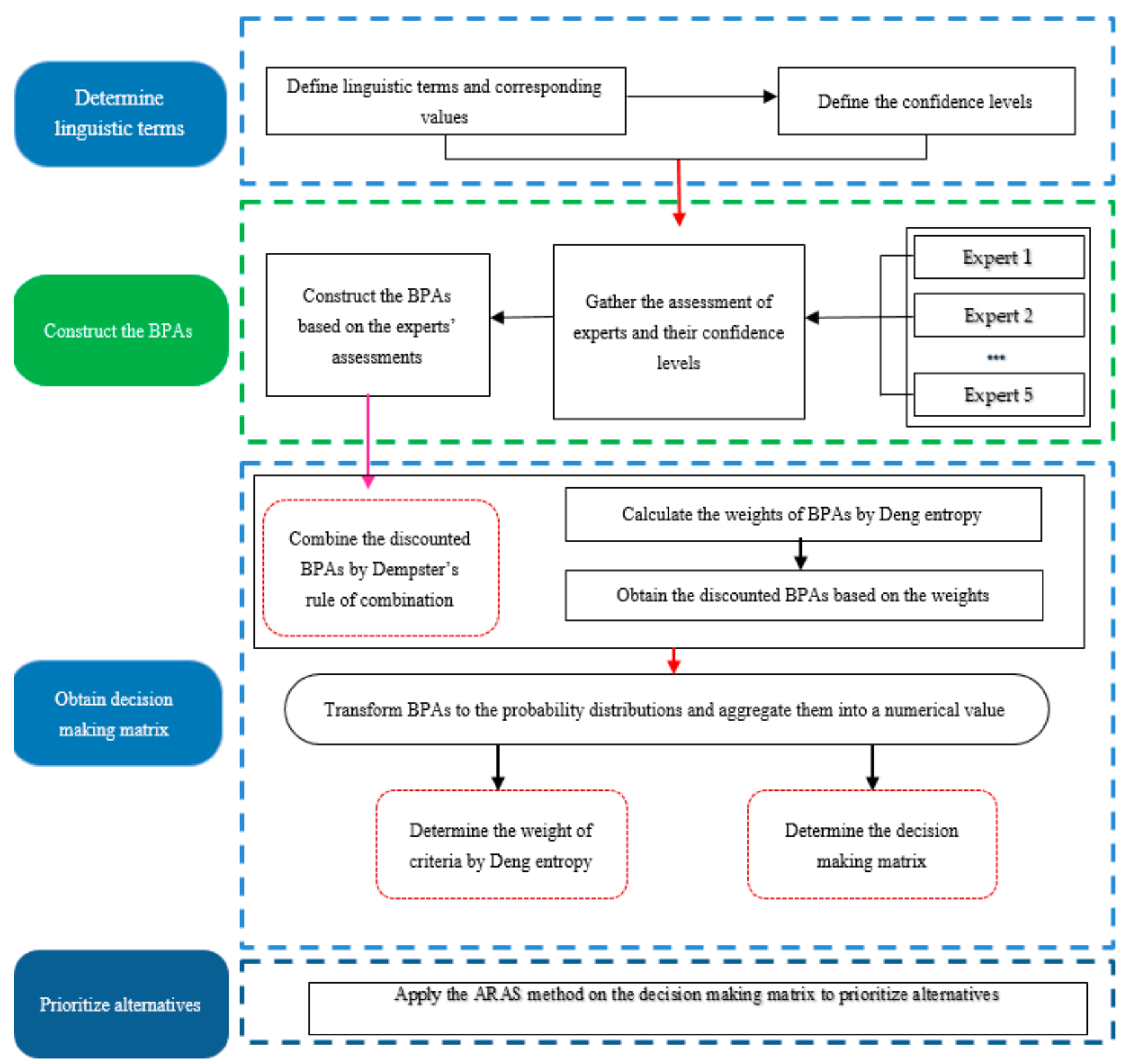

Figure 2. The flow chart of the proposed DS evidence theory and ARAS method.

Step 1: Define linguistic terms, corresponding values, and confidence levels In multi-criteria decision-making problems, the ratings of alternatives for evaluation criteria must be determined. For doing so, the linguistic terms presented in Table 2 are used to evaluate alternatives concerning the evaluation criteria. Furthermore, Table 3 is used to help experts to assign confidence levels to their opinions about evaluation criteria. For instance, if an expert selects very low importance with a confidence level of 0.6 , the expert is adequately convinced that the importance level is very low. 
Table 2. Linguistic terms and their corresponding value [106].

\begin{tabular}{cccc}
\hline Importance & Abbreviation & Linguistic Judgment & Corresponding Values \\
\hline Very low & $\mathrm{VL}$ & $\begin{array}{c}\text { Almost no recognition of the } \\
\text { performance } \\
\text { Low evaluation of the } \\
\text { performance }\end{array}$ & 1 \\
Medium & $\mathrm{L}$ & $\mathrm{M}$ & $\begin{array}{c}\text { The level of the performance } \\
\text { is medium } \\
\text { High }\end{array}$ \\
Very high & $\mathrm{H}$ & $\begin{array}{c}\text { High evaluation of the } \\
\text { performance }\end{array}$ & 4 \\
\hline
\end{tabular}

Table 3. The confidence levels [106].

\begin{tabular}{cc}
\hline Confidence Level & Scale \\
\hline Fully convinced & 1 \\
Almost convinced & 0.8 \\
Properly convinced & 0.6 \\
Some convinced & 0.4 \\
Almost not convinced & 0.2 \\
Completely not convinced & 0 \\
Some intermediate values between two & $0.9,0.7,0.5,0.3,0.1$ \\
adjacent levels & \\
\hline
\end{tabular}

Step 2: Convert experts' assessments to BPAs

In this step, the experts' judgments and their confidence levels are used to determine the BPAs. There are five elements in linguistic terms shown in Table 1 for rating alternatives. These elements are considered as the frame of discernment, and experts' assessment levels are considered the focal elements. Furthermore, the confidence levels determined by experts about their assessments can be seen as beliefs. Suppose that $x_{i j}$ denotes the rating of alternative $i$ for criterion $j$ and the respected evaluation levels in $x_{i j}$ are $A, B, \ldots$, and the corresponding confidence levels are $a, b, \ldots$. The BPA for this judgment can be written as follows:

$$
\begin{gathered}
m(A)=a \\
m(B)=b \\
\vdots \\
m(\theta)=1-a-b
\end{gathered}
$$

For example, if an expert selects very low and low assessment levels with confidence levels $0.6,0.1$, respectively, the respected BPA can be denoted as: $m(V L)=0.6, m(L)=$ $0.1, m(\theta)=0.3$.

Step 3: Obtain the discounted BPAs

In this step, the discounted BPA is obtained for BPAs based on the weights of that BPA. For doing so, Deng entropy is first calculated based on Equation (4) to determine the entropy measure for a given BPA. Then, the weight of that BPA is calculated according to Equations (5)-(7). Finally, the discounted BPA is obtained by applying Equation (8).

Step 4: Combine the discounted BPAs

In this step, after obtaining the discounted BPAs associated with $x_{i j}$ for each expert, they are combined by Dempster's rule presented in Equations (9) and (10).

Step 5: Apply the pignistic probability transformation

As the combined results for discounted BPAs are in the form of focal elements with mass function values, the pignistic probability transformation is used to convert them into a singleton element concerning linguistic terms of criteria. In this step, the pignistic probability transformation for each linguistic term of criteria is provided based on the 
Equation (11). To obtain a numerical value for each criterion, the probability distribution must be integrated. For doing so, suppose that we have $n$ linguistic terms with ratings $L_{1}, L_{2}, \ldots, L_{n}$ for evaluating a criterion. Furthermore, let $P_{1}, P_{2}, \ldots, P_{n}$ be the probability distribution concerning $n$ linguistic terms. Then, the aggregated value, which is the mathematical expectation value of the criterion, is calculated as:

$$
\text { Aggregated value }=L_{1} P_{1}+L_{2} P_{2}+\ldots+L_{n} P_{n}
$$

Step 6: Apply the ARAS method to prioritize alternatives

By applying step 5, the decision-making matrix is constructed. After that, the ARAS method formulated in Equations (12)-(20) is applied to the decision-making matrix to calculate alternative utility. Finally, alternatives are prioritized according to alternative utility $\left(K_{i}\right)$.

\section{Application of the Proposed Method for Sustainable Material Selection}

In this section, the proposed method assesses the exterior enclosure materials based on the sustainability indicators. The exterior enclosure materials cover the buildings, protect them against undesirable climatic conditions, and maintain the optimum internal temperature. In this study, alternatives are considered as five materials used in the exterior of the building. They are aluminum siding $\left(A_{1}\right)$, clay brick $\left(A_{2}\right)$, glass facade $\left(A_{3}\right)$, brick and mortar wall $\left(\mathrm{A}_{4}\right)$, and stone facade $\left(\mathrm{A}_{5}\right)$. These alternatives must be assessed based on sustainable criteria. The sustainable criteria for the construction material selection problem are extracted from the literature review. They are categorized into four groups: economic, environmental, socio-cultural, and technical criteria, and presented in Table 4.

Table 4. Sustainable material selection criteria [30,108].

\begin{tabular}{ccc}
\hline Criteria & Sub-Criteria & Notation \\
\hline & Design and construction time & $\mathrm{C}_{11}$ \\
& Operational cost & $\mathrm{C}_{12}$ \\
Economic criterion $\left(\mathrm{C}_{1}\right)$ & Cost of maintenance/repairs/service & $\mathrm{C}_{13}$ \\
& The durability of the building & $\mathrm{C}_{14}$ \\
& Market sentiment/public acceptance & $\mathrm{C}_{15}$ \\
& Return to baseline & $\mathrm{C}_{16}$ \\
& Transportation cost & $\mathrm{C}_{17}$ \\
\hline \multirow{3}{*}{ Socio-cultural criterion $\left(\mathrm{C}_{2}\right)$} & The comfort of the occupants & $\mathrm{C}_{21}$ \\
& Impact on the local economy & $\mathrm{C}_{22}$ \\
& Workforce safety and health & $\mathrm{C}_{23}$ \\
& Preservation of cultural heritage & $\mathrm{C}_{24}$ \\
& Customer acceptance and satisfaction & $\mathrm{C}_{25}$ \\
& Skilled workforce availability & $\mathrm{C}_{26}$ \\
\hline Environmental criterion $\left(\mathrm{C}_{3}\right)$ & Wef renewable materials and energy & $\mathrm{C}_{31}$ \\
& Water and Wastewater Productivity & $\mathrm{C}_{32}$ \\
& Strategies & $\mathrm{C}_{33}$ \\
& Regional materials & $\mathrm{C}_{34}$ \\
& Waste Management & $\mathrm{C}_{35}$
\end{tabular}

The data must be gathered based on the experts' opinions. For this purpose, five architects with more than ten years of experience in designing and construction were 
considered. According to step 1 of the proposed method, a questionnaire was used to ask about the status of criteria in each alternative. According to step 2 of the proposed method, the experts' opinions must be converted to BPAs. For example, according to the first expert opinion, the rating of alternative $\mathrm{A}_{1}$ in terms of sub-criterion $\mathrm{C}_{11}$ is $\{H, V H\}$ with a confidence level of 0.65 . The respected BPA for this assessment is $m(\{H, V H\})=$ $0.65, m(\theta)=0.35$ (Objective 1). These steps of the proposed method and their explanations refer to objective 1 of the paper.

In step 3 of the proposed method, the discounted BPAs must be obtained. First, Deng entropy is calculated for each BPA according to Equation (4). Then, Equations (5)-(8) are used to calculate the weight of BPA and the discounted BPA, respectively. The maximum Deng entropy is calculated by Equations (5) and (6), and its value becomes 7.72. For the aforementioned BPA in the previous example, Deng's entropy value and the respected weight are calculated as 3.70 and 0.52, respectively. According to these results and Equation (8), the discounted BPA can be written as $m(\{H, V H\})=0.34, m(\theta)=0.66$.

Similarly, the discounted BPAs are provided for all experts' evaluations. After that, according to step 4 of the proposed method, Dempster's rule of combination is utilized to combine the discounted BPAs extracted from experts' evaluations. Table 5 reports the combined results. In other words, Table 5 shows the decision matrix obtained from the aggregation of expert opinions. The decision matrix is reported in terms of BPAs in Table 5, which addresses objective 2 of the paper, which is shown in Table 5 . In step 5 of the proposed method, the combined discounted BPAs are used to obtain the pignistic probability transformation for each linguistic term. Then, they are aggregated by Equation (24). Table 6 reports Betp and aggregated values for each alternative under different criteria.

Table 5. The combined discounted BPAs extracted from experts' evaluations.

\begin{tabular}{ccc}
\hline Criteria & Alternatives & Combined BPA \\
& $\mathrm{A}_{1}$ & $\mathrm{~m}(\{\mathrm{VH}\})=1, \mathrm{~m}(\theta)=0$ \\
& $\mathrm{~A}_{2}$ & $\mathrm{~m}(\{\mathrm{M}\})=0.56, \mathrm{~m}(\{\mathrm{H}, \mathrm{VH}\})=0.16, \mathrm{~m}(\theta)=0.28$ \\
$\mathrm{C}_{11}$ & $\mathrm{~A}_{3}$ & $\mathrm{~m}(\{\mathrm{M}, \mathrm{L}\})=0.12, \mathrm{~m}(\{\mathrm{M}\})=0.14, \mathrm{~m}(\{\mathrm{H}\})=0.32, \mathrm{~m}(\theta)=0.42$ \\
& $\mathrm{~A}_{4}$ & $\mathrm{~m}(\{\mathrm{VL}\})=0.03, \mathrm{~m}(\{\mathrm{M}\})=0.09, \mathrm{~m}(\{\mathrm{H}\})=0.53, \mathrm{~m}(\theta)=0.35$ \\
& $\mathrm{~A}_{5}$ & $\mathrm{~m}(\{\mathrm{M}\})=0.08, \mathrm{~m}(\{\mathrm{H}\})=0.2, \mathrm{~m}(\{\mathrm{VH}\})=0.41, \mathrm{~m}(\theta)=0.31$ \\
\hline & $\mathrm{A}_{1}$ & $\mathrm{~m}(\{\mathrm{VH}\})=1, \mathrm{~m}(\theta]=0$ \\
& $\mathrm{~A}_{2}$ & $\mathrm{~m}(\{\mathrm{H}\})=0.1, \mathrm{~m}(\{\mathrm{VH}\})=0.72, \mathrm{~m}(\theta)=0.18$ \\
$\mathrm{C}_{22}$ & $\mathrm{~A}_{3}$ & $\mathrm{~m}(\{\mathrm{M}\})=0.58, \mathrm{~m}(\{\mathrm{H}\})=0.16, \mathrm{~m}(\theta)=0.26$ \\
& $\mathrm{~A}_{4}$ & $\mathrm{~m}(\{\mathrm{VL}\})=0.04, \mathrm{~m}(\{\mathrm{~L}\})=0.03, \mathrm{~m}(\{\mathrm{M}\})=0.59, \mathrm{~m}(\theta)=0.34$ \\
& $\mathrm{~A}_{5}$ & $\mathrm{~m}(\{\mathrm{~L}\})=0.02, \mathrm{~m}(\{\mathrm{M}\})=0.11, \mathrm{~m}(\{\mathrm{H}, \mathrm{VH}\})=0.49, \mathrm{~m}(\theta)=0.38$ \\
\hline & $\vdots$ & $\mathrm{m}(\{\mathrm{VH}\})=1, \mathrm{~m}(\theta)=0$ \\
& $\mathrm{~A}_{1}$ & $\mathrm{~m}(\{\mathrm{M}, \mathrm{H}\})=1, \mathrm{~m}(\theta)=0$ \\
& $\mathrm{~A}_{2}$ & $\mathrm{~m}(\{\mathrm{M}\})=0.11, \mathrm{~m}(\{\mathrm{M}, \mathrm{H}]=0.05, \mathrm{~m}(\{\mathrm{VH})=0.48, \mathrm{~m}(\theta)=0.36$ \\
& $\mathrm{A}_{3}$ & $\mathrm{~m}(\{\mathrm{VL}\})=0.003, \mathrm{~m}(\{\mathrm{H}\})=0.68, \mathrm{~m}(\{\mathrm{H}, \mathrm{VH}\})=0.2, \mathrm{~m}(\theta)=0.117$ \\
$\mathrm{~A}_{4}$ & $\mathrm{~m}(\{\mathrm{~L}\})=0.01, \mathrm{~m}(\{\mathrm{M}\})=0.19, \mathrm{~m}(\{\mathrm{VH}\})=0.44, \mathrm{~m}(\theta)=0.36$ \\
& $\mathrm{~A}_{5}$ &
\end{tabular}

Table 6. Betp and aggregated values for each alternative under different criteria.

\begin{tabular}{|c|c|c|c|c|c|c|c|}
\hline \multirow{2}{*}{ Criteria } & \multirow{2}{*}{ Alternatives } & \multicolumn{5}{|c|}{ Betp } & \multirow{2}{*}{ Aggregated Values } \\
\hline & & $(\{V L\})$ & $(\{L\})$ & $(\{\mathbf{M}\})$ & $(\{\mathbf{H}\})$ & $(\{\mathrm{VH}\})$ & \\
\hline \multirow{5}{*}{$\mathrm{C}_{11}$} & $A_{1}$ & 0 & 0 & 0 & 0 & 1 & 5 \\
\hline & $\mathrm{A}_{2}$ & 0.056 & 0.056 & 0.616 & 0.136 & 0.136 & 3.24 \\
\hline & $\mathrm{A}_{3}$ & 0.084 & 0.144 & 0.284 & 0.404 & 0.084 & 3.26 \\
\hline & $\mathrm{A}_{4}$ & 0.1 & 0.07 & 0.16 & 0.6 & 0.07 & 3.47 \\
\hline & $\mathrm{A}_{5}$ & 0.062 & 0.062 & 0.142 & 0.262 & 0.472 & 4.02 \\
\hline
\end{tabular}


Table 6. Cont

\begin{tabular}{|c|c|c|c|c|c|c|c|}
\hline \multirow{2}{*}{ Criteria } & \multirow{2}{*}{ Alternatives } & \multicolumn{5}{|c|}{ Betp } & \multirow{2}{*}{ Aggregated Values } \\
\hline & & $(\{\mathrm{VL}\})$ & $(\{\mathbf{L}\})$ & $(\{\mathbf{M}\})$ & $(\{\mathbf{H}\})$ & $(\{\mathrm{VH}\})$ & \\
\hline \multirow{5}{*}{$\mathrm{C}_{12}$} & $\mathrm{~A}_{1}$ & 0 & 0 & 0 & 0 & 1 & 5.00 \\
\hline & $\mathrm{A}_{2}$ & 0.036 & 0.036 & 0.036 & 0.136 & 0.756 & 4.54 \\
\hline & $\mathrm{A}_{3}$ & 0.052 & 0.052 & 0.342 & 0.212 & 0.052 & 2.29 \\
\hline & $\mathrm{A}_{4}$ & 0.108 & 0.098 & 0.658 & 0.068 & 0.068 & 2.89 \\
\hline & $\mathrm{A}_{5}$ & 0.072 & 0.092 & 0.072 & 0.212 & 0.552 & 4.08 \\
\hline \multirow{5}{*}{$\mathrm{C}_{45}$} & $\mathrm{~A}_{1}$ & 0.158 & 0.158 & 0.263 & 0.263 & 0.158 & 3.10 \\
\hline & $\mathrm{A}_{2}$ & 0.062 & 0.082 & 0.132 & 0.062 & 0.662 & 4.18 \\
\hline & $\mathrm{A}_{3}$ & 0.044 & 0.044 & 0.044 & 0.574 & 0.294 & 4.03 \\
\hline & $\mathrm{A}_{4}$ & 0.051 & 0.051 & 0.046 & 0.426 & 0.426 & 4.12 \\
\hline & $\mathrm{A}_{5}$ & 0.064 & 0.334 & 0.064 & 0.064 & 0.474 & 3.55 \\
\hline \multirow{5}{*}{$\mathrm{C}_{46}$} & $\mathrm{~A}_{1}$ & 0 & 0 & 0 & 0 & 1 & 5.00 \\
\hline & $\mathrm{A}_{2}$ & 0.072 & 0.072 & 0.207 & 0.097 & 0.552 & 3.98 \\
\hline & $\mathrm{A}_{3}$ & 0 & 0 & 0.500 & 0.500 & 0 & 3.500 \\
\hline & $\mathrm{A}_{4}$ & 0.025 & 0.022 & 0.022 & 0.802 & 0.022 & 3.45 \\
\hline & $\mathrm{A}_{5}$ & 0.072 & 0.082 & 0.262 & 0.072 & 0.512 & 3.87 \\
\hline
\end{tabular}

The aggregated results reported in Table 6 form the decision-making matrix, which is presented in Table 7. In the last step of the proposed model, the ARAS method is applied to the decision-making matrix to obtain the alternative utility $\left(K_{i}\right)$. The ARAS method presented in Equations (12)-(20) is employed.

Table 7. Decision-making matrix.

\begin{tabular}{|c|c|c|c|c|c|c|c|c|c|c|}
\hline & $C_{11}$ & $C_{12}$ & $\mathrm{C}_{13}$ & $C_{14}$ & $C_{15}$ & $C_{16}$ & $\mathrm{C}_{17}$ & $\mathrm{C}_{21}$ & $\mathrm{C}_{22}$ & $\mathrm{C}_{23}$ \\
\hline $\mathrm{A}_{1}$ & 5 & 5 & 3.552 & 5 & 5 & 1.840 & 2.236 & 5 & 1.992 & 3.600 \\
\hline$A_{2}$ & 3.072 & 4.324 & 2.484 & 2.876 & 3.620 & 3.780 & 3.168 & 3.148 & 2.334 & 4.005 \\
\hline $\mathrm{A}_{3}$ & 2.756 & 1.874 & 5 & 1.790 & 2.345 & 1.556 & 1.752 & 1.752 & 2.208 & 1.690 \\
\hline $\mathrm{A}_{4}$ & 2.980 & 2.278 & 2.776 & 2.577 & 4.250 & 3.310 & 2.458 & 3.435 & 3.710 & 2.726 \\
\hline \multirow[t]{2}{*}{$\mathrm{A}_{5}$} & 3.834 & 3.792 & 3.792 & 3.834 & 3.038 & 2.985 & 3.834 & 3.834 & 3.656 & 2.630 \\
\hline & $C_{24}$ & $\mathrm{C}_{25}$ & $C_{26}$ & $C_{31}$ & $C_{32}$ & $\mathrm{C}_{33}$ & $\mathrm{C}_{34}$ & $\mathrm{C}_{35}$ & $C_{36}$ & $\mathrm{C}_{41}$ \\
\hline $\mathrm{A}_{1}$ & 5 & 3.828 & 2.787 & 5 & 1.848 & 1.632 & 2.258 & 2.862 & 2.89 & 3.843 \\
\hline $\mathrm{A}_{2}$ & 2.566 & 3.498 & 3.422 & 0.559 & 3.498 & 2.820 & 2.010 & 2.952 & 2.576 & 3.217 \\
\hline $\mathrm{A}_{3}$ & 2.248 & 1.740 & 1.230 & 3.562 & 1.455 & 2.118 & 1.803 & 1.563 & 3.784 & 2.345 \\
\hline $\mathrm{A}_{4}$ & 1 & 1.990 & 2.970 & 2.955 & 0.240 & 0.216 & 2.956 & 3.395 & 4.139 & 5 \\
\hline \multirow[t]{2}{*}{$\mathrm{A}_{5}$} & 3.384 & 2.430 & 2.430 & 1.944 & 2.664 & 2.664 & 2.208 & 3.036 & 3.766 & 5 \\
\hline & $\mathrm{C}_{42}$ & $\mathrm{C}_{43}$ & $\mathrm{C}_{44}$ & $\mathrm{C}_{45}$ & $\mathrm{C}_{46}$ & & & & & \\
\hline $\mathrm{A}_{1}$ & 2.756 & 3.116 & 3.240 & 3.895 & 5 & & & & & \\
\hline$A_{2}$ & 3.594 & 3.948 & 3.870 & 3.870 & 3.769 & & & & & \\
\hline $\mathrm{A}_{3}$ & 2.348 & 2.5 & 3.038 & 3.766 & 3.500 & & & & & \\
\hline $\mathrm{A}_{4}$ & 3.425 & 3.843 & 3.696 & 3.987 & 3.233 & & & & & \\
\hline $\mathrm{A}_{5}$ & 2.756 & 3.116 & 3.240 & 3.895 & 5 & & & & & \\
\hline
\end{tabular}

After obtaining the decision-making matrix, it is normalized according to Equations (15) and (1 To calculate the weight of criteria, the combined discounted BPAs reported in Table 5 are used again to combine different BPAs of alternatives under the same criterion. Then, Equations (17)-(19) are utilized to calculate the weight of criteria. Table 8 reports the combined BPAs of alternatives under the same criterion and the weight of sub-criteria. Table 8 addresses objective 3 of the paper. 
Table 8. Combined BPAs and weights for each sub-criterion.

\begin{tabular}{|c|c|c|c|c|}
\hline Criteria & Combined BPA & $E_{j}$ & $D_{j}$ & $w_{j}$ \\
\hline $\mathrm{C}_{11}$ & $\mathrm{~m}(\{\mathrm{VH}\})=1, \mathrm{~m}(\theta)=0$ & 0 & 1 & 0.055 \\
\hline $\mathrm{C}_{12}$ & $\mathrm{~m}(\{\mathrm{VH}\})=1, \mathrm{~m}(\theta)=0$ & 0 & 1 & 0.055 \\
\hline $\mathrm{C}_{13}$ & $\mathrm{~m}(\{\mathrm{VH}\})=1, \mathrm{~m}(\theta)=0$ & 0 & 1 & 0.055 \\
\hline $\mathrm{C}_{14}$ & $\mathrm{~m}(\{\mathrm{VH}\})=1, \mathrm{~m}(\theta)=0$ & 0 & 1 & 0.055 \\
\hline $\mathrm{C}_{15}$ & $\mathrm{~m}(\{\mathrm{VH}\})=1, \mathrm{~m}(\theta)=0$ & 0 & 1 & 0.055 \\
\hline $\mathrm{C}_{16}$ & $\begin{array}{c}\mathrm{m}(\{\mathrm{L}]=0.006, \mathrm{~m}(\{\mathrm{M}, \mathrm{L}\})=0.001 \\
\mathrm{m}(\{\mathrm{M}\})=0.16, \mathrm{~m}(\{\mathrm{M}, \mathrm{H}\})=0.16, \mathrm{~m}(\{\mathrm{H}\}) \\
=0.01, \mathrm{~m}(\{\mathrm{VH}\})=0.33, \mathrm{~m}(\theta)=0.33\end{array}$ & 3.93 & 0.49 & 0.027 \\
\hline $\mathrm{C}_{17}$ & $\begin{array}{c}\mathrm{m}(\{\mathrm{L}\})=0.0005, \mathrm{~m}(\{\mathrm{M}\})=0.21, \mathrm{~m}(\{\mathrm{~L}, \mathrm{H}\}) \\
=0.004, \mathrm{~m}(\{\mathrm{H}\})=0.22, \mathrm{~m}(\{\mathrm{VH}\})=0.004 \\
\mathrm{~m}(\theta)=0.56\end{array}$ & 4.27 & 0.45 & 0.025 \\
\hline $\mathrm{C}_{21}$ & $\mathrm{~m}(\{\mathrm{VH}\})=1, \mathrm{~m}(\theta)=0$ & 0 & 1 & 0.055 \\
\hline $\mathrm{C}_{22}$ & $\begin{array}{c}\mathrm{m}(\{\mathrm{VL}, \mathrm{L}\})=0.0007, \mathrm{~m}(\{\mathrm{~L}\})=0.0002 \\
\mathrm{~m}(\{\mathrm{M}, \mathrm{L}\})=0.001, \mathrm{~m}(\{\mathrm{M}\})=0.29 \\
\mathrm{~m}(\{\mathrm{M}, \mathrm{H}\})=0.02, \mathrm{~m}(\{\mathrm{H}\})=0.5 \\
\mathrm{~m}(\{\mathrm{VH}\})=0.04, \mathrm{~m}(\theta)=0.14\end{array}$ & 2.46 & 0.68 & 0.038 \\
\hline $\mathrm{C}_{23}$ & $\begin{array}{c}\mathrm{m}(\{\mathrm{VL}]=0.001, \mathrm{~m}(\{\mathrm{~L}\})=0.01 \\
\mathrm{m}(\{\mathrm{M}, \mathrm{L}\})=0.05, \mathrm{~m}(\{\mathrm{M}\})=0.05 \\
\mathrm{~m}(\{\mathrm{H}\})=0.15, \mathrm{~m}(\{\mathrm{H}, \mathrm{VH}\})=0.01 \\
\mathrm{~m}(\theta)=0.72\end{array}$ & 4.46 & 0.42 & 0.023 \\
\hline $\mathrm{C}_{24}$ & $\begin{array}{c}\mathrm{m}(\{\mathrm{M}\})=0.13, \mathrm{~m}(\{\mathrm{M}, \mathrm{H}\})=0.19 \\
\mathrm{~m}(\{\mathrm{H}\})=0.22, \mathrm{~m}(\{\mathrm{H}, \mathrm{VH}\})=0.23 \\
\mathrm{~m}(\theta)=0.23\end{array}$ & 4.10 & 0.47 & 0.026 \\
\hline $\mathrm{C}_{25}$ & $\begin{array}{c}\mathrm{m}(\{\mathrm{L}\})=0.04, \mathrm{~m}(\{\mathrm{M}\})=0.2, \mathrm{~m}(\{\mathrm{H}\})=0.01 \\
\mathrm{~m}(\{\mathrm{H}, \mathrm{VH}\})=0.006, \mathrm{~m}(\{\mathrm{VH}\})=0.48 \\
\mathrm{~m}(\theta)=0.26\end{array}$ & 3.07 & 0.6 & 0.033 \\
\hline $\mathrm{C}_{26}$ & $\begin{array}{c}\mathrm{m}(\{\mathrm{VL}\})=0.004, \mathrm{~m}(\{\mathrm{~L}\})=0.009, \mathrm{~m}(\{\mathrm{M}, \mathrm{L}\}) \\
=0.001, \mathrm{~m}(\{\mathrm{M}\})=0.009, \mathrm{~m}(\{\mathrm{H}\})=0.27 \\
\mathrm{~m}(\{\mathrm{VH}\})=0.44, \mathrm{~m}(\theta)=0.26\end{array}$ & 2.99 & 0.61 & 0.034 \\
\hline $\mathrm{C}_{31}$ & $\mathrm{~m}(\{\mathrm{VH}\})=1, \mathrm{~m}(\theta)=0$ & 0 & 1 & 0.055 \\
\hline $\mathrm{C}_{32}$ & $\begin{array}{l}\mathrm{m}(\{\mathrm{VL}\})=0.005, \mathrm{~m}(\{\mathrm{M}, \mathrm{L}\})=0.02, \mathrm{~m}(\{\mathrm{M}\}) \\
\quad=0.51, \mathrm{~m}(\{\mathrm{VH}\})=0.1, \mathrm{~m}(\theta)=0.36\end{array}$ & 3.32 & 0.57 & 0.032 \\
\hline $\mathrm{C}_{33}$ & $\begin{array}{c}\mathrm{m}(\{\mathrm{VL}\})=0.002, \mathrm{~m}(\{\mathrm{~L}\})=0.002 \\
\mathrm{~m}(\{\mathrm{M}\})=0.34, \mathrm{~m}(\{\mathrm{H}\})=0.42, \mathrm{~m}(\theta)=0.23\end{array}$ & 2.72 & 0.65 & 0.036 \\
\hline $\mathrm{C}_{34}$ & $\begin{array}{c}\mathrm{m}(\{\mathrm{VL}\})=0.002, \mathrm{~m}(\{\mathrm{~L}\})=0.11, \mathrm{~m}(\{\mathrm{M}, \mathrm{L}\}) \\
=0.004, \mathrm{~m}(\{\mathrm{M}\})=0.2, \mathrm{~m}(\{\mathrm{H}\})=0.4 \\
\mathrm{~m}(\theta)=0.23\end{array}$ & 3.30 & 0.57 & 0.032 \\
\hline $\mathrm{C}_{35}$ & $\begin{array}{l}\mathrm{m}(\{\mathrm{VL}\})=0.003, \mathrm{~m}(\{\mathrm{M}, \mathrm{L}\})=0.002, \mathrm{~m}(\{\mathrm{H}\}) \\
\quad=0.84, \mathrm{~m}(\{\mathrm{H}, \mathrm{VH}\})=0.001, \mathrm{~m}(\theta)=0.11\end{array}$ & 1.16 & 0.85 & 0.047 \\
\hline $\mathrm{C}_{36}$ & $\begin{array}{c}\mathrm{m}(\{\mathrm{L}\})=0.001, \mathrm{~m}(\{\mathrm{M}\})=0.003 \\
\mathrm{~m}(\{\mathrm{M}, \mathrm{H}\})=0.12, \mathrm{~m}(\{\mathrm{H}\})=0.61 \\
\mathrm{~m}(\{\mathrm{H}, \mathrm{VH}\})=0.07, \mathrm{~m}(\{\mathrm{VH}\})=0.01 \\
\mathrm{~m}(\theta)=0.09\end{array}$ & 2.23 & 0.71 & 0.039 \\
\hline $\mathrm{C}_{41}$ & $\mathrm{~m}(\{\mathrm{VH}\})=1, \mathrm{~m}(\theta)=0$ & 0 & 1 & 0.055 \\
\hline $\mathrm{C}_{42}$ & $\begin{array}{c}\mathrm{m}(\{\mathrm{VL}\})=0.0009, \mathrm{~m}(\{\mathrm{~L}\})=0.01 \\
\mathrm{~m}(\{\mathrm{M}\})=0.14, \mathrm{~m}(\{\mathrm{H}\})=0.31 \\
\mathrm{~m}(\{\mathrm{H}, \mathrm{VH}\})=0.1, \mathrm{~m}(\{\mathrm{VH}\})=0.23 \\
\mathrm{~m}(\theta)=0.2\end{array}$ & 3.43 & 0.56 & 0.031 \\
\hline
\end{tabular}


Table 8. Cont.

\begin{tabular}{|c|c|c|c|c|}
\hline Criteria & Combined BPA & $E_{j}$ & $D_{j}$ & $w_{j}$ \\
\hline $\mathrm{C}_{43}$ & $\begin{array}{c}\mathrm{m}(\{\mathrm{VL}\})=0.001, \mathrm{~m}(\{\mathrm{~L}\})=0.001 \\
\mathrm{~m}(\{\mathrm{M}\})=0.29, \mathrm{~m}(\{\mathrm{M}, \mathrm{H}\})=0.0004 \\
\mathrm{~m}(\{\mathrm{H}\})=0.45, \mathrm{~m}(\{\mathrm{H}, \mathrm{VH}\})=0.01 \\
\mathrm{~m}(\{\mathrm{VH}\})=0.18, \mathrm{~m}(\theta)=0.23\end{array}$ & 3.22 & 0.58 & 0.032 \\
\hline $\mathrm{C}_{44}$ & $\begin{array}{c}\mathrm{m}(\{\mathrm{L}]=0.009, \mathrm{~m}(\{\mathrm{M}\})=0.12 \\
\mathrm{m}(\{\mathrm{H}\})=0.23, \mathrm{~m}(\{\mathrm{H}, \mathrm{VH}\})=0.009 \\
\mathrm{~m}(\{\mathrm{VH}\})=0.28, \mathrm{~m}(\theta)=0.35\end{array}$ & 3.77 & 0.51 & 0.028 \\
\hline $\mathrm{C}_{45}$ & $\begin{array}{c}\mathrm{m}(\{\mathrm{VL}\})=0.001, \mathrm{~m}(\{\mathrm{VL}, \mathrm{L}\})=0.007 \\
\mathrm{~m}(\{\mathrm{~L}\})=0.17, \mathrm{~m}(\{\mathrm{M}\})=0.007, \mathrm{~m}(\{\mathrm{H}, \mathrm{VH}\}) \\
\quad=0.09, \mathrm{~m}(\{\mathrm{VH}\})=0.05, \mathrm{~m}(\theta)=0.67\end{array}$ & 4.93 & 0.36 & 0.020 \\
\hline $\mathrm{C}_{46}$ & $\mathrm{~m}(\{\mathrm{VH}\})=1, \mathrm{~m}(\theta)=0$ & 0 & 1 & 0.055 \\
\hline
\end{tabular}

The weights of criteria reported in Table 8 are used to obtain the normalized-weighted decision-making matrix. According to the results of Table 8, the weight values of the economic, socio-cultural, environmental, and technical criteria are equal to $0.327,0.209$, 0.241 , and 0.221 , respectively. The weight value of each criterion is equal to the sum of the weight value of its sub-criteria. The results reveal the economic criteria are the most important in the material selection process.

Among the criteria for evaluating the sustainability of materials, design and construction time $\left(C_{11}\right)$, operational cost $\left(C_{12}\right)$, cost of maintenance/repairs/service $\left(C_{13}\right)$, transportation cost $\left(C_{17}\right)$, greenhouse gases $\left(C_{35}\right)$, and weight of material $\left(C_{41}\right)$ are considered as the cost type criteria and the rest are the profit criteria. In our case, the optimal value is used as $x_{0 j}=5$ for the benefit type criteria, and it is considered as $x_{0 j}=1$ for the cost type criteria. Finally, the optimality function and alternative utility are calculated and presented in Table 9. The last column of Table 9 shows the rank of alternatives. Table 9 presents objective 4 of the paper. According to the results, aluminum siding $\left(\mathrm{A}_{1}\right)$ is the best sustainable material that can be used for a building façade. Clay brick $\left(A_{2}\right)$ is determined as the second sustainable material for a building facade. Furthermore, stone facade $\left(A_{5}\right)$, brick and mortar walls $\left(\mathrm{A}_{4}\right)$, and glass facade $\left(\mathrm{A}_{3}\right)$ were ranked third to fifth, respectively, in terms of sustainability.

Table 9. ARAS results.

\begin{tabular}{cccc}
\hline Alternative & $\boldsymbol{S}_{\boldsymbol{i}}$ & $\boldsymbol{K}_{\boldsymbol{i}}$ & Rank \\
\hline $\mathrm{A}_{0}$ & 0.290 & 1.000 & - \\
$\mathrm{A}_{1}$ & 0.156 & 0.538 & 1 \\
$\mathrm{~A}_{2}$ & 0.143 & 0.494 & 2 \\
$\mathrm{~A}_{3}$ & 0.131 & 0.450 & 5 \\
$\mathrm{~A}_{4}$ & 0.137 & 0.472 & 4 \\
$\mathrm{~A}_{5}$ & 0.140 & 0.482 & 3 \\
\hline
\end{tabular}

\section{Conclusions}

In this paper, an evidential model was developed based on the Dempster-Shafer theory of evidence and the ARAS method for the sustainable building material selection problem under uncertainty. The experts' assessment and their confidence levels are used to construct the BPAs. The evidential model supports the decisions when information is unclear or conflicts. It was the first attempt to apply the DS evidence theory to solve the sustainable material selection problem. Furthermore, the ARAS method was employed to prioritize five sustainable materials in building facades. Integrating the DS theory and the ARAS method can deal with uncertain information effectively and provides a reasonable solution for the sustainable material selection problem. 
Deng entropy was utilized to calculate the weights of criteria and their sub-criteria. The weight values of the economic, socio-cultural, environmental, and technical criteria were calculated as $0.327,0.209,0.241$, and 0.221 , respectively. These results show that economic criteria are the most important criteria in the sustainable material selection process. According to the results of the ARAS method, the alternative utility values for aluminum siding $\left(A_{1}\right)$, clay brick $\left(A_{2}\right)$, and stone facade $\left(A_{5}\right)$ are equal to $0.538,0.494$, and 0.482 , respectively. These results reveal that aluminum siding is the best sustainable material among the five materials studied in this article. Clay brick (A2) and stone facade (A5) are in the second and third rank values in terms of sustainability, respectively.

It is worth mentioning that the effectiveness of the proposed DS evidence theory and ARAS method is illustrated through a real case study. In future research, the proposed method should be applied to more practice to further verify its feasibility. In some cases where there are conflicts among evidence, the results may be unreliable. Therefore, the existence of conflicts can be considered as one of the limitations of using evidence theory. It is an interesting topic for future research to develop a modified model based on the evidence theory to solve the sustainable material selection problem by considering the conflicts.

Author Contributions: Conceptualization, S.M.H., H.A., Z.T. and J.T.; methodology, S.M.H., Z.T. and J.T.; software, H.A.; validation, G.S.; formal analysis, S.M.H., G.S., Z.T. and J.T.; investigation, S.M.H. and H.A.; data curation, H.A.; writing-original draft preparation, S.M.H.; writing-review and editing, J.T. and Z.T.; visualization, J.T. and Z.T.; supervision, J.T. and Z.T.; project administration, J.T. All authors have read and agreed to the published version of the manuscript.

Funding: This research received no external funding.

Institutional Review Board Statement: Not applicable.

Informed Consent Statement: Not applicable.

Data Availability Statement: Data available on request due to restrictions.

Acknowledgments: The authors are grateful for the valuable comments and suggestions of the respected reviewers. These comments enhanced the strength and significance of our paper.

Conflicts of Interest: Authors declare no conflict of interest.

\section{Appendix A}

Table A1. The definition of the variables and notations.

\begin{tabular}{clll}
\hline \multicolumn{1}{c}{ Symbol } & \multicolumn{1}{c}{ Description } & Symbol & \multicolumn{1}{c}{ Description } \\
\hline$\theta$ & $\begin{array}{l}\text { The frame of } \\
\text { discernment }\end{array}$ & $|A|$ & $\begin{array}{l}\text { The cardinality of } \\
\text { proposition } A\end{array}$ \\
\hline$H_{1}, H_{2}, \ldots, H_{n}$ & hypotheses & Bet $P\{x\}$ & $\begin{array}{l}\text { The pignistic } \\
\text { probability } \\
\text { transformation for } \\
x \in \theta\end{array}$ \\
\hline $2^{\theta}$ & The power set of $\theta$ & $X$ & $\begin{array}{l}\text { The decision-making } \\
\text { matrix }\end{array}$ \\
\hline$m(A)$ & $\begin{array}{l}\text { a member of the } \\
\text { power set }\end{array}$ & $x_{i j}$ & $\begin{array}{l}\text { The rating of } \\
\text { alternative } i \text { for } \\
\text { criterion } j\end{array}$ \\
\hline & The mass function of & $x_{0 j}$ & $\begin{array}{l}\text { The optimal value of } j \\
\text { th criterion }\end{array}$ \\
\hline
\end{tabular}


Table A1. Cont.

\begin{tabular}{|c|c|c|c|}
\hline Symbol & Description & Symbol & Description \\
\hline$E(B P A)$ & $\begin{array}{l}\text { Deng entropy for a } \\
\text { BPA or a mass } \\
\text { function }\end{array}$ & $\bar{X}$ & $\begin{array}{l}\text { The normalized } \\
\text { decision-making } \\
\text { matrix }\end{array}$ \\
\hline$E_{\max }$ & $\begin{array}{l}\text { Maximum value of } \\
\text { Deng entropy }\end{array}$ & $\hat{X}$ & $\begin{array}{l}\text { The } \\
\text { normalized-weighted } \\
\text { decision-making } \\
\text { matrix }\end{array}$ \\
\hline$F_{i}$ & $\begin{array}{l}\text { A proposition in mass } \\
\text { function }\end{array}$ & $w_{j}$ & $\begin{array}{l}\text { The weight of } j \text { th } \\
\text { criterion }\end{array}$ \\
\hline$\left|F_{i}\right|$ & $\begin{array}{l}\text { The number of } \\
\text { elements of } F_{i}\end{array}$ & $D_{j}$ & $\begin{array}{l}\text { The consistency of } \\
\text { alternatives for } j \\
\text { criterion }\end{array}$ \\
\hline$w(B P A)$ & $\begin{array}{l}\text { The weight of a given } \\
\text { BPA }\end{array}$ & $E_{j}$ & $\begin{array}{l}\text { The entropy of } j \\
\text { criterion }\end{array}$ \\
\hline$\alpha$ & $\begin{array}{l}\text { Discounting } \\
\text { coefficient }\end{array}$ & $S_{i}$ & $\begin{array}{l}\text { The optimality } \\
\text { function of } \\
\text { alternative } i\end{array}$ \\
\hline$m^{\alpha}(A)$ & $\begin{array}{l}\text { The discounted BPA } \\
\text { for } \mathrm{A}\end{array}$ & $K_{i}$ & The alternative utility \\
\hline$m^{\alpha}(\theta)$ & $\begin{array}{l}\text { The discounted BPA } \\
\text { for } \theta\end{array}$ & $A_{1}, A_{2}, \ldots, A_{m}$ & Alternatives \\
\hline$k$ & $\begin{array}{l}\text { The conflict between } \\
\text { two BPAs }\end{array}$ & $C_{1}, C_{2}, \ldots, C_{n}$ & criteria \\
\hline
\end{tabular}

\section{References}

1. Peldschus, F.; Zavadskas, E.K.; Turskis, Z.; Tamosaitiene, J. Sustainable assessment of construction site by applying game theory. Inz. Ekon.-Eng. Econ. 2010, 21, 223-237.

2. Akadiri, P.O. Understanding barriers affecting the selection of sustainable materials in building projects. J. Build. Eng. 2015, 4, 86-93. [CrossRef]

3. Zavadskas, E.K.; Kaklauskas, A.; Turskis, Z.; Tamosaitiene, J.; Kalibatas, D. Assessment of the indoor environment of dwelling houses by applying the COPRAS-G method: Lithuania case study. Environ. Eng. Manag. J. 2011, 10, 637-647. [CrossRef]

4. Roy, J.; Das, S.; Kar, S.; Pamučar, D. An extension of the CODAS approach using interval-valued intuitionistic fuzzy set for sustainable material selection in construction projects with incomplete weight information. Symmetry 2019, 11, 393. [CrossRef]

5. Zavadskas, E.K.; Turskis, Z.; Volvačiovas, R.; Kildiene, S. Multi-criteria assessment model of technologies. Stud. Inform. Control 2013, 22, 249-258. [CrossRef]

6. Zavadskas, E.K.; Kaklauskas, A.; Turskis, Z.; Kalibatas, D. An approach to multi-attribute assessment of indoor environment before and after refurbishment of dwellings. J. Environ. Eng. Landsc. Manag. 2009, 17, 5-11. [CrossRef]

7. Erdogan, S.A.; Šaparauskas, J.; Turskis, Z. Decision making in construction management: AHP and expert choice approach. Procedia Eng. 2017, 172, 270-276. [CrossRef]

8. Mathiyazhagan, K.; Gnanavelbabu, A.; Prabhuraj, B.L. A sustainable assessment model for material selection in construction industries perspective using hybrid MCDM approaches. J. Adv. Manag. Res. 2019, 16, 234-259. [CrossRef]

9. American Institute of Architecture (AIA) Material Selection \& Specification. 2012. Available online: http://www.aia.org/ aiaucmp/groups/aia/documents/pdf/aiab097628.pdf (accessed on 22 May 2020).

10. Karabasevic, D.; Zavadskas, E.K.; Turskis, Z.; Stanujkic, D. The framework for the selection of personnel based on the SWARA and ARAS methods under uncertainties. Informatica 2016, 27, 49-65. [CrossRef]

11. Hashemkhani Zolfani, S.; Zavadskas, E.K.; Turskis, Z. Design of products with both International and Local perspectives based on Yin-Yang balance theory and SWARA method. Econ. Res.-Ekon. Istraživanja 2013, 26, 153-166. [CrossRef]

12. Zavadskas, E.K.; Vilutiene, T.; Turskis, Z.; Tamosaitiene, J. Contractor selection for construction works by applying SAW-G and TOPSIS grey techniques. J. Bus. Econ. Manag. 2010, 11, 34-55. [CrossRef]

13. Bagočius, V.; Zavadskas, E.K.; Turskis, Z. Multi-person selection of the best wind turbine based on the multi-criteria integrated additive-multiplicative utility function. J. Civ. Eng. Manag. 2014, 20, 590-599. [CrossRef]

14. Zavadskas, E.K.; Turskis, Z.; Tamosaitiene, J. Selection of construction enterprises management strategy based on the SWOT and multi-criteria analysis. Arch. Civ. Mech. Eng. 2011, 11, 1063-1082. [CrossRef] 
15. Ruzgys, A.; Volvačiovas, R.; Ignatavičius, Č.; Turskis, Z. Integrated evaluation of external wall insulation in residential buildings using SWARA-TODIM MCDM method. J. Civ. Eng. Manag. 2014, 20, 103-110. [CrossRef]

16. Turskis, Z.; Dzitac, S.; Stankiuviene, A.; Šukys, R. A Fuzzy Group Decision-making Model for Determining the Most Influential Persons in the Sustainable Prevention of Accidents in the Construction SMEs. Int. J. Comput. Commun. Control 2019, 14, 90-106. [CrossRef]

17. Turskis, Z.; Lazauskas, M.; Zavadskas, E.K. Fuzzy multiple criteria assessment of construction site alternatives for non-hazardous waste incineration plant in Vilnius city, applying ARAS-F and AHP methods. J. Environ. Eng. Landsc. Manag. 2012, 20, 110-120. [CrossRef]

18. Kibert, C.J. Sustainable Construction: Green Building Design and Delivery, 2nd ed.; John Wiley and Sons, Inc.: Hoboken, NJ, USA, 2008.

19. Medineckiene, M.; Zavadskas, E.K.; Björk, F.; Turskis, Z. Multi-criteria decision-making system for sustainable building assessment/certification. Arch. Civ. Mech. Eng. 2015, 15, 11-18. [CrossRef]

20. Chatterjee, K.; Zavadskas, E.K.; Tamošaitienė, J.; Adhikary, K.; Kar, S. A hybrid MCDM technique for risk management in construction projects. Symmetry 2018, 10, 46. [CrossRef]

21. Esin, A. Properties of Material for Design; METU Printing Office: Gaziantep, Turkey, 1980.

22. Akadiri, P.O.; Olomolaiye, P.O. Development of sustainable assessment criteria for building materials selection. Eng. Constr. Archit. Manag. 2012, 19, 111-187. [CrossRef]

23. Mousavi-Nasab, S.H.; Sotoudeh-Anvari, A. A new multi-criteria decision making approach for sustainable material selection problem: A critical study on rank reversal problem. J. Clean. Prod. 2018, 182, 466-484. [CrossRef]

24. Keshavarz Ghorabaee, M.; Zavadskas, E.K.; Turskis, Z.; Antucheviciene, J. A new combinative distance-based assessment (CODAS) method for multi-criteria decision-making. Econ. Comput. Econ. Cybern. Stud. Res. 2016, 50, $25-44$.

25. Rezaei, J. Best-worst multi-criteria decision-making method. Omega 2015, 53, 49-57. [CrossRef]

26. Govindan, K.; Shankar, K.M.; Kannan, D. Sustainable material selection for construction industry-A hybrid multi criteria decision making approach. Renew. Sustain. Energy Rev. 2016, 55, 1274-1288. [CrossRef]

27. Gabus, A.; Fontela, E. World Problems an Invitation to Further Thought within the Framework of DEMATEL; Battelle Geneva Research Centre: Geneva, Switzerland, 1972.

28. Saaty, T.L. The Analytic Network Process; RWS Publications: Pittsburgh, PA, USA, 1996.

29. Hwang, C.L.; Yoon, K. Multiple Attribute Decision Making: Methods and Applications: A State-of-the-Art Survey; Springer: Berlin/Heidelberg, Germany, 1981.

30. Mahmoudkelaye, S.; Azari, K.T.; Pourvaziri, M.; Asadian, E. Sustainable material selection for building enclosure through ANP method. Case Stud. Constr. Mater. 2018, 9, e00200. [CrossRef]

31. Zavadskas, E.K.; Bausys, R.; Juodagalviene, B.; Garnyte-Sapranaviciene, I. Model for residential house element and material selection by neutrosophic MULTIMOORA method. Eng. Appl. Artif. Intell. 2017, 64, 315-324. [CrossRef]

32. Keršuliene, V.; Zavadskas, E.K.; Turskis, Z. Selection of rational dispute resolution method by applying new step-wise weight assessment ratio analysis (SWARA). J. Bus. Econ. Manag. 2010, 11, 243-258. [CrossRef]

33. Brauers, W.K.M.; Zavadskas, E.K. Project management by MULTIMOORA as an instrument for transition economies. Technol. Econ. Dev. Econ. 2010, 16, 5-24. [CrossRef]

34. Chen, Z.S.; Martínez, L.; Chang, J.P.; Wang, X.J.; Xionge, S.H.; Chin, K.S. Sustainable building material selection: A QFD- and ELECTRE III-embedded hybrid MCGDM approach with consensus building. Eng. Appl. Artif. Intell. 2019, 85, 783-807. [CrossRef]

35. Reddy, A.S.; Kumar, P.R.; Raj, P.A. Preference based multi-criteria framework for developing a Sustainable Material Performance Index (SMPI). Int. J. Sustain. Eng. 2019, 12, 390-403. [CrossRef]

36. Zavadskas, E.; Turskis, Z. A new additive ratio assessment (ARAS) method in multi criteria decision making. Technol. Econ. Dev. Econ. 2010, 16, 159-172. [CrossRef]

37. Turskis, Z.; Zavadskas, E.K. A new fuzzy additive ratio assessment method (ARAS-F). Case study: The analysis of fuzzy multiple criteria in order to select the logistic centers location. Transport 2010, 25, 423-432. [CrossRef]

38. Turskis, Z.; Zavadskas, E.K. A Novel Method for Multiple Criteria Analysis: Grey Additive Ratio Assessment (ARAS-G) Method. Informatica 2010, 21, 597-610. [CrossRef]

39. Zavadskas, E.K.; Turskis, Z.; Vilutiene, T. Multiple criteria analysis of foundation instalment alternatives by applying Additive Ratio Assessment (ARAS) method. Arch. Civ. Mech. Eng. 2010, 10, 123-141. [CrossRef]

40. Susinskas, S.; Zavadskas, E.K.; Turskis, Z. Multiple Criteria Assessment of Pile-Columns Alternatives. Balt. J. Road Bridge 2011, 6, 145-152. [CrossRef]

41. Kersuliene, V.; Turskis, Z. Integrated Fuzzy Multiple Criteria Decision Making Model For Architect Selection. Technol. Econ. Dev. Econ. 2011, 17, 645-666. [CrossRef]

42. Sivilevicius, H.; Daniunas, A.; Zavadskas, E.K.; Turskis, Z.; Susinskas, S. Experimental Study on Technological Indicators of Pile-Columns at A Construction Site. J. Civ. Eng. Manag. 2012, 18, 512-518. [CrossRef]

43. Zavadskas, E.K.; Vainiunas, P.; Turskis, Z.; Tamosaitiene, J. Multiple Criteria Decision Support System For Assessment of Projects Managers in Construction. Int. J. Inf. Technol. Decis. Mak. 2012, 11, 501-520. [CrossRef]

44. Balezentis, A.; Balezentis, T.; Misiunas, A. An Integrated Assessment of Lithuanian Economic Sectors Based on Financial Ratios and Fuzzy MCDM Methods. Technol. Econ. Dev. Econ. 2012, 18, 34-53. [CrossRef] 
45. Turskis, Z.; Zavadskas, E.K.; Kutut, V. A Model Based on ARAS-G and AHP methods for multiple criteria prioritizing of heritage value. Int. J. Inf. Technol. Decis. Mak. 2013, 12, 45-73. [CrossRef]

46. Kutut, V.; Zavadskas, E.K.; Lazauskas, M. Assessment of Priority Options for Preservation of Historic City Centre Buildings Using MCDM (ARAS). In Proceedings of the 11th International Scientific Conference on Modern Building Materials, Structures and Techniques (MBMST), Vilnius, Lithuania, 16-17 May 2013; Modern Building Materials, Structures and Techniques; Book Series: Procedia Engineering. Volume 57, pp. 657-661. [CrossRef]

47. Kersuliene, V.; Turskis, Z. An integrated multi-criteria group decision making process: Selection of the chief accountant. Procedia Soc. Behav. Sci. 2014, 110, 897-904. [CrossRef]

48. Shariati, S.; Yazdani-Chamzini, A.; Salsani, A.; Tamosaitiene, J. Proposing a New Model for Waste Dump Site Selection: Case Study of Ayerma Phosphate Mine. Inz. Ekon.-Eng. Econ. 2014, 25, 410-419. [CrossRef]

49. Zamani, M.; Rabbani, A.; Yazdani-Chamzini, A.; Turskis, Z. An Integrated Model For Extending Brand Based On Fuzzy ARAS and ANP Methods. J. Bus. Econ. Manag. 2014, 15, 403-423. [CrossRef]

50. Safaei Ghadikolaei, A.; Khalili Esbouei, S.; Antucheviciene, J. Applying Fuzzy Mcdm For Financial Performance Evaluation Of Iranian Companies. Technol. Econ. Dev. Econ. 2014, 20, 274-291. [CrossRef]

51. Zavadskas, E.K.; Turskis, Z.; Bagočius, V. Multi-criteria selection of a deep-water port in the Eastern Baltic Sea. Appl. Soft Comput. 2015, 26, 180-192. [CrossRef]

52. Stanujkic, D. Extension of the ARAS Method for Decision-Making Problems with Interval-Valued Triangular Fuzzy Numbers. Informatica 2015, 26, 335-355. [CrossRef]

53. Akhavan, P.; Barak, S.; Maghsoudlou, H.; Antucheviciene, J. FQSPM-SWOT for strategic alliance planning and partner selection; case study in a holding car manufacturer company. Technol. Econ. Dev. Econ. 2015, 21, 165-185. [CrossRef]

54. Karabasevic, D.; Paunkovic, J.; Stanujkic, D. ranking of companies according to the indicators of corporate social responsibility based on SWARA and ARAS methods. Serb. J. Manag. 2016, 11, 43-53. [CrossRef]

55. Martinez-Gomez, J. Use of multicriteria decision making methods for biomass selection in fischer tropsch reactors. Ingenius-Rev. de Cienc. Y Tecnol. 2016, 15, 27-36. [CrossRef]

56. Turskis, Z.; Juodagalviene, B. A novel hybrid multi-criteria decision-making model to assess a stairs shape for dwelling houses. J. Civ. Eng. Manag. 2016, 22, 1078-1087. [CrossRef]

57. Hashemkhani Zolfani, S.; Maknoon, R.; Zavadskas, E.K. An Introduction To Prospective Multiple Attribute Decision Making (PMADM). Technol. Econ. Dev. Econ. 2016, 22, 309-326. [CrossRef]

58. Nguyen, H.T.; Dawal, S.Z.M.; Nukman, Y.; Rifai, A.P.; Aoyama, H. An Integrated MCDM Model for Conveyor Equipment Evaluation and Selection in an FMC Based on a Fuzzy AHP and Fuzzy ARAS in the Presence of Vagueness. PLoS ONE 2016, 11, e0153222. [CrossRef]

59. Varmazyar, M.; Dehghanbaghi, M.; Afkhami, M. A novel hybrid MCDM model for performance evaluation of research and technology organizations based on BSC approach. Eval. Program Plan. 2016, 58, 125-140. [CrossRef]

60. Balezentis, T.; Streimikiene, D. Multi-criteria ranking of energy generation scenarios with Monte Carlo simulation. Appl. Energy 2017, 185 Pt 1, 862-871. [CrossRef]

61. Tamosaitiene, J.; Zavadskas, E.K.; Sileikaite, I.; Turskis, Z. A novel hybrid MCDM approach for complicated supply chain management problems in construction. In Proceedings of the 12th International Conference on Modern Building Materials, Structures and Techniques (MBMST), Vilnius, Lithuania, 26-27 May 2016; Modern Building Materials, Structures and Techniques. Volume 172, pp. 1137-1145. [CrossRef]

62. Turskis, Z.; Kersuliene, V.; Vinogradova, I. A new Fuzzy Hybrid Multi-Criteria Decision-Making Approach to Solve Personnel Assessment Problems. Case Study: Directo Selection for Estates and economy office. Econ. Comput. Econ. Cybern. Stud. Res. 2017, 51, 211-229.

63. Stanujkic, D.; Zavadskas, E.K.; Karabasevic, D.; Turskis, Z.; Kersuliene, V. New group Decision-Making ARCAS approach based on the integration of the SWARA and the ARAS methods adapted for negotiations. J. Bus. Econ. Manag. 2017, 18, 599-618. [CrossRef]

64. Turskis, Z.; Morkunaite, Z.; Kutut, V. A Hybrid Multiple Criteria Evaluation Method of Ranking of Cultural Heritage Structures for Renovation Projects. Int. J. Strateg. Prop. Manag. 2017, 21, 318-329. [CrossRef]

65. Dahooie, J.H.; Abadi, E.B.J.; Vanaki, A.S.; Firoozfar, H.R. Competency-based IT personnel selection using a hybrid SWARA and ARAS-G methodology. Hum. Factors Ergon. Manuf. Serv. Ind. 2018, 28, 5-16. [CrossRef]

66. Ecer, F. An Integrated Fuzzy Ahp and Aras Model to Evaluate Mobile Banking Services. Technol. Econ. Dev. Econ. 2018, 24, 670-695. [CrossRef]

67. Singaravel, B.; Shankar, D.P.; Prasanna, L. Application of MCDM Method for the Selection of Optimum Process Parameters in Turning Process. Mater. Today-Proc. 2018, 5 Pt 2, 13464-13471. [CrossRef]

68. Emovon, I.; Mgbemena, C.O. Machinery/Service system Scheduled Replacement time determination: A combine Weighted Aggregated Sum Product Assessment, Additive Ratio Assessment and Age Replacement Model approach. Int. J. Integr. Eng. 2018, 10, 169-175. [CrossRef]

69. Arabameri, A.; Pradhan, B.; Pourghasemi, H.R.; Rezaei, K. Identification of erosion-prone areas using different multi-criteria decision-making techniques and GIS. Geomat. Nat. Hazards Risk 2018, 9, 1129-1155. [CrossRef] 
70. Yapici Pehlivan, N.; Sahin, A.; Zavadskas, E.K.; Turskis, Z. A Comparative Study Of Integrated Fmcdm Methods For Evaluation of Organizational Strategy Development. J. Bus. Econ. Manag. 2018, 19, 360-381. [CrossRef]

71. Cherrez-Troya, M.; Martinez-Gomez, J.; Peralta-Zurita, D.; Llanes-Cedeno, E.A. Multi-Criteria Methods Applied in The Selection of A Brake Disc Material. Ingenius-Rev. Cienc. Tecnol. 2018, 20, 83-95. [CrossRef]

72. Radovic, D.; Stevic, Z.; Pamucar, D.; Zavadskas, E.K.; Badi, I.; Antucheviciene, J.; Turskis, Z. Measuring Performance in Transportation Companies in Developing Countries: A Novel Rough ARAS Model. Symmetry 2018, 10, 434. [CrossRef]

73. Mardani, A.; Jusoh, A.; Halicka, K.; Ejdys, J.; Magruk, A.; Ahmad, U.N.U. Determining the utility in management by using multi-criteria decision support tools: A review. Econ. Res.-Ekon. Istraz. 2018, 31, 1666-1716. [CrossRef]

74. Martin, N.; Deepak, F.X.E. Application of New Additive Ratio Assessment (NARAS) Method in Selection of Material for Optimal Design of Engineering Components. Mater. Today-Proc. 2019, 11 Pt 3, 1049-1053. [CrossRef]

75. Boranbayev, A.S.; Boranbayev, S.N.; Nurusheva, A.M.; Seitkulov, Y.N.; Sissenov, N.M. A method to determine the level of the information system fault-tolerance. Eurasian J. Math. Comput. Appl. 2019, 7, 13-32. [CrossRef]

76. Pehlivan, N.Y.; Gursoy, Z. Determination of individuals' life satisfaction levels living in Turkey by FMCDM methods. Kybernetes 2019, 48, 1871-1893. [CrossRef]

77. Kumar, A.; Hussain, S.A.; Rai, R.N. Optimization by AHP-ARAS of EDM Process Parameters on Machining AA7050-10\%B4C Composite. In Proceedings of the 1st International Conference on Future Learning Aspects for Mechanical Engineering (FLAME), Noida, India, 3-5 October 2018; Advances In Industrial and Production Engineering; Book Series: Lecture Notes in Mechanical Engineering. pp. 285-296. [CrossRef]

78. Ulutas, A. Supplier Selection by Using a Fuzzy Integrated Model for a Textile Company. Inz. Ekon.-Eng. Econ. 2019, 30, 579-590. [CrossRef]

79. Rani, P.; Mishra, A.R.; Ansari, M.D. Analysis of Smartphone Selection Problem under Interval-valued Intuitionistic Fuzzy ARAS and TOPSIS Methods. In Proceedings of the 5th International Conference on Image Information Processing (ICIIP 2019), Waknaghat, India, 15-17 November 2019; pp. 509-514.

80. Chalekaee, A.; Turskis, Z.; Khanzadi, M.; Amiri, G.G.; Kersuliene, V. A New Hybrid MCDM Model with Grey Numbers for the Construction Delay Change Response Problem. Sustainability 2019, 11, 776. [CrossRef]

81. Turskis, Z.; Urbonas, K.; Daniunas, A. A Hybrid Fuzzy Group Multi-Criteria Assessment of Structural Solutions of the Symmetric Frame Alternatives. Symmetry 2019, 11, 261. [CrossRef]

82. Fu, Y.K. An integrated approach to catering supplier selection using AHP-ARAS-MCGP methodology. J. Air Transp. Manag. 2019, 75, 164-169. [CrossRef]

83. Matic, B.; Jovanovic, S.; Das, D.K.; Zavadskas, E.K.; Stevic, Z.; Sremac, S.; Marinkovic, M. A New Hybrid MCDM Model: Sustainable Supplier Selection in a Construction Company. Symmetry 2019, 11, 353. [CrossRef]

84. Iordache, M.; Schitea, D.; Deveci, M.; Akyurt, I.Z.; Iordache, L. An integrated ARAS and interval type-2 hesitant fuzzy sets method for underground site selection: Seasonal hydrogen storage in salt caverns. J. Pet. Sci. Eng. 2019, 175, 1088-1098. [CrossRef]

85. Yalcin, N.; Pehlivan, N.Y. Application of the Fuzzy CODAS Method Based on Fuzzy Envelopes for Hesitant Fuzzy Linguistic Term Sets: A Case Study on a Personnel Selection Problem. Symmetry 2019, 11, 493. [CrossRef]

86. Dahooie, J.H.; Zavadskas, E.K.; Vanaki, A.S.; Firoozfar, H.R.; Lari, M.; Turskis, Z. A new evaluation model for corporate financial performance using integrated CCSD and FCM-ARAS approach. Econ. Res.-Ekon. Istraz. 2019, 32, 1088-1113. [CrossRef]

87. Ighravwe, D.E.; Oke, S.A. A multi-criteria decision-making framework for selecting a suitable maintenance strategy for public buildings using sustainability criteria. J. Build. Eng. 2019, 24, 100753. [CrossRef]

88. Ecer, F. A Multi-criteria Approach Towards Assessing Corporate Sustainability Performances of Privately-owned Banks: EntropyARAS Integrated Model. Eskiseh. Osman. Univ. IIBF Derg.-Eskiseh. Osman. Univ. J. Econ. Adm. Sci. 2019, 14, 365-390. [CrossRef]

89. Zavadskas, E.K.; Stevic, Z.; Turskis, Z.; Tomasevic, M. A Novel Extended EDAS in Minkowski Space (EDAS-M) Method for Evaluating Autonomous Vehicles. Stud. Inform. Control 2019, 28, 255-264. [CrossRef]

90. Bahrami, Y.; Hassani, H.; Maghsoudi, A. BWM-ARAS: A new hybrid MCDM method for Cu prospectivity mapping in the Abhar area, NW Iran. Spat. Stat. 2019, 33, 100382. [CrossRef]

91. Petrovic, G.; Mihajlovic, J.; Cojbasic, Z.; Madic, M.; Marinkovic, D. Comparison of three fuzzy MCDM methods for solving the supplier selection problem. Facta Univ.-Ser. Mech. Eng. 2019, 17, 455-469. [CrossRef]

92. Buyukozkan, G.; Guler, M. Analysis of companies' digital maturity by hesitant fuzzy linguistic MCDM methods. J. Intell. Fuzzy Syst. 2020, 38, 1119-1132. [CrossRef]

93. Ulutas, A.; Karakus, C.B.; Topal, A. Location selection for logistics center with fuzzy SWARA and CoCoSo methods. J. Intell. Fuzzy Syst. 2020, 38, 4693-4709. [CrossRef]

94. Zagorskas, J.; Turskis, Z. Location Preferences Of New Pedestrian Bridges Based On Multi-Criteria Decision-Making And Gis-Based Estimation. Balt. J. Road Bridge Eng. 2020, 15, 158-181. [CrossRef]

95. Ghenai, C.; Albawab, M.; Bettayeb, M. Sustainability indicators for renewable energy systems using multi-criteria decision-making model and extended SWARA/ARAS hybrid method. Renew. Energy 2020, 146, 580-597. [CrossRef]

96. Boyaci, A.C. Selection of eco-friendly cities in Turkey via a hybrid hesitant fuzzy decision making approach. Appl. Soft Comput. 2020, 89, 106090. [CrossRef] 
97. Prajapati, H.; Kant, R.; Tripathi, S.M. An integrated framework for prioritizing the outsourcing performance outcomes. J. Glob. Oper. Strateg. Sourc. 2020, 13, 301-325. [CrossRef]

98. Mishra, A.R.; Sisodia, G.; Pardasani, K.R.; Sharma, K. Multi-criteria IT personnel selection on intuitionistic fuzzy information measures and ARAS methodology. Iran. J. Fuzzy Syst. 2020, 17, 55-68.

99. Jocic, K.J.; Jocic, G.; Karabasevic, D.; Popovic, G.; Stanujkic, D.; Zavadskas, E.K.; Nguyen, P.T. A Novel Integrated PIPRECIAInterval-Valued Triangular Fuzzy ARAS Model: E-Learning Course Selection. Symmetry 2020, 12, 928. [CrossRef]

100. Dempster, A.P. Upper and lower probabilities introduced by multivalued mappings. Ann. Inst. Stat. Math. 1967, 38, 325-339. [CrossRef]

101. Shafer, G. A Mathematical Theory of Evidence; Princeton University Press: Princeton, NJ, USA, 1976.

102. Wu, W.Z.; Zhang, M.; Li, H.Z.; Mi, J.S. Knowledge reduction in random information systems via Dempster-Shafer theory of evidence. Inf. Sci. 2005, 174, 143-164. [CrossRef]

103. Yang, B.; Kim, K.J. Application of Dempster-Shafer theory in fault diagnosis of induction motors using vibration and current signals. Mech. Syst. Signal Process. 2006, 20, 403-420. [CrossRef]

104. Liu, Y.Z.; Jiang, Y.C.; Liu, X.; Yang, S.L. CSMC: A combination strategy for multi-class classification based on multiple association rules. Knowl.-Based Syst. 2008, 21, 786-793. [CrossRef]

105. Xiao, Z.; Yang, X.; Niu, Q.; Dong, Y.; Gong, K.; Xia, S.; Pang, Y. A new evaluation method based on D-S generalized fuzzy soft sets and its application in medical diagnosis problem. Appl. Math. Model. 2012, 36, 4592-4604. [CrossRef]

106. Fei, L.; Deng, Y.; Hu, Y. DS-VIKOR: A new multi-criteria decision-making method for supplier selection. Int. J. Fuzzy Syst. 2019, 21, 157-175. [CrossRef]

107. Deng, Y. Deng Entropy. Chaos Solitons Fractals 2016, 91, 549-553. [CrossRef]

108. Kamali, M.; Hewage, K.; Milani, A.S. Life cycle sustainability performance assessment framework for residential modular buildings: Aggregated sustainability indices. Build. Environ. 2018, 138, 21-41. [CrossRef] 